\title{
Do High-Skill Immigrants trigger High-Quality Trade?
}

\author{
Giorgia Giovannetti ${ }^{1,2}$ and Mauro Lanati ${ }^{2}$ \\ ${ }^{1}$ Department of Economics and Management, University of Firenze, Firenze, Italy and ${ }^{2}$ Robert Schuman \\ Centre for Advanced Studies, European University Institute, Fiesole, Italy
}

\section{INTRODUCTION}

$\mathfrak{I}^{N}$ $\mathrm{N}$ the last decades, the world economy witnessed an increase in international integration. Exports rose from 21.6 per cent of world GDP in 1995 to 29.9 per cent in 2013 World Bank, and foreign direct investment (inward stock) from 9.7 per cent to 34.3 per cent between 1995 and 2013. ${ }^{1}$ Over the same period, international migrants increased substantially also: the total number of migrants rose by 50.1 per cent between 1990 and 2013 and nowadays around 231 million people (approximately 3 per cent of the world's population) are living in countries other than their countries of birth. ${ }^{2}$

These trends are likely to be closely connected. Indeed, this rise in the stock of immigrants has been often related to trade flows. Empirically, the possible bi-univocal relationship triggered contrasting results and a lack of consensus on the direction of causation; while there seems to be some agreement on the strong and significant correlation of the stock of immigrants in the receiving country and the amount of trade with their country of origin, particularly evident for high-skilled migrants (see for instance Herander and Saavedra 2005; Felbermayr and Jung 2009; Felbermayr and Toubal 2012). More specifically, international migrants could enhance bilateral trade by lowering information costs and increasing demand for goods from their source countries. There is a fairly established literature on the trade cost channel of migration, that is the role the ethnic networks play in triggering trade by reducing information costs: the empirical analysis was first confined to case studies level but, more recently, the gravity approach has been extended to multi-country analysis. ${ }^{3}$ The existing literature assumes that both imports and exports are symmetrically affected by improved information while only imports from source country depend on migrants' preferences. The preference channel of migration hinges on the difference in tastes between immigrants and natives: it reflects the tendency of immigrants to prefer goods they were consuming at home, since it may take time for them to adjust their tastes to the destination country's culture and usage. Against this background, high-skilled migrants tend to impact more on trade because of lower

We are especially grateful to an anonymous referee for insightful suggestions. We also thank Alasdair Smith (University of Sussex), Juan Dolado (EUI), Ramon Marimon (EUI), Luca De Benedictis (University of Macerata) and Giuseppe De Arcangelis (University of Rome - La Sapienza) for helpful comments and feedback.

${ }^{1}$ Data are from World Bank's Development Indicators. Data on FDI are from UNCTAD (2014).

2 These figures on migrants are from UN (2013).

${ }^{3}$ Information costs include the cost for acquiring information on distribution networks, the cost to find the right component suppliers or the investors to find joint-venture partners. These costs also include adapting exporters' products to consumer preferences in a given country, adapting the marketing strategies to a specific context and adjusting commodities to different qualitative and technical standards (see Rauch 2001). 
liquidity constraints and advantages in their human capital that imply lower costs. Indeed, on the one hand better education is likely to help ethnic networks to boost their informational advantages so that migrants may become more effective in promoting and facilitating international trade; on the other hand, more educated migrants could, in principle, strengthen the preference channel simply because they earn and possess higher incomes (see Felbermayr et al. 2012). Building on this literature, this paper tests whether, and to what extent, the relationship between ethnic networks and trade varies with product quality. More precisely, we investigate how the pro-trade effect of immigrants varies with the quality of traded products over the period 1995-2000. To our knowledge, the link between product quality and the protrade elasticity of ethnic networks has not yet been explored in the literature. Existing studies mainly focus on the variation of the pro-trade effect of ethnic networks due to different levels of goods' heterogeneity, following the methodology adopted - among others - by Rauch and Trindade (2002). We adopt a similar approach by classifying traded goods according to their quality level and separately estimating pro-trade elasticity of ethnic networks for each subgroup.

We expect that the relationship between product quality and pro-trade elasticity of ethnic networks will be highly dependent on the North-South specialisation across varieties. On the supply side, since emerging and OECD economies specialise in different bundles of varieties (see Schott 2004; Fontagné et al. 2008), ethnic networks will mostly facilitate imports of those varieties for which their countries of origin have a comparative advantage. On the demand side, given difference in the market positioning of the various exporters on their different destination markets (see Fontagné et al. 2008), we expect ethnic networks to be more effective in promoting exports to their homeland of those varieties for which there is relatively higher demand. Furthermore, our hypothesis is that the relationship between product quality and pro-trade elasticity of ethnic networks will largely depend on the composition of the stock of immigrants by skill level. Given their lower liquidity constraints and advantages in human capital, the pro-trade effect of high-skilled migrants is likely to affect relatively more high-quality goods. Our empirical analysis aims at testing these conjectures.

We follow the trade-migration literature by incorporating the stock of immigrants (whole stock and high skill) into an augmented gravity model. The proxy for ethnic networks is included in a general gravity expression derived from a supply-side Ricardian model of trade à la Eaton and Kortum (2002) which predicts the North-South specialisation across quality segments that emerge from the findings of Schott (2004) and Fontagné et al. (2008). Along with the other standard trade cost proxies in the econometric specification, we also include HS-6 digit industry fixed effects which enable to capture non-observable industry specific characteristics. As in Gould (1994), we distinguish between imports and exports and we separately analyse the effect on differentiated products. Our data set covers approximately 30 per cent of the global stock of migrants: the extensive country coverage - 177 countries of origin and 19 OECD destinations - attenuates the sample selection bias due to the specific choice of the countries entering the analysis and it allows to exploit differences between countries at different income levels. Following Fontagné et al. (2008), we utilise unit values as a proxy for product quality. As in Hallak (2006), we assume that all cross-country variation in export unit values can be attributed to differences in quality.

Five main results stand out: (i) as the sample expands to include emerging economies, the pro-trade effect of immigrants decreases significantly; (ii) for all levels of income and for any level of quality the high-skilled ethnic networks have a stronger impact on trade; (iii) the proexport effects are always larger: this seems to suggests that the trade cost channel of 
migration is likely to dominate the preference channel; (iv) the trend of the pro-trade effect of immigrants over quality is driven by the North-South specialisation across varieties for both supply and demand; and (v) these trends apply regardless the degree of product differentiation based on the classification proposed by Rauch (1999).

\section{LITERATURE REVIEW}

\section{a. Trade-Migration Link}

Since the seminal contribution of Gould (1994), several papers using different samples, time coverage and econometric techniques have investigated the relationships between bilateral trade and migration flows to find a strong and significant empirical correlation between the stock of immigrants in the destination country and the volume of trade with their country of origin (see Parsons and Winters 2014). As mentioned above, the underlying idea is that migrants have a comparative advantage in conveying reliable information on markets which are very different from the host country. These could be the origin countries but also countries which are similar to the origin in terms of religion, culture and structure of the society. The majority of the contributions study the pro-trade effect of immigrants into a single country, while relatively few papers focus on a multicountry analysis. With the recent availability of more and better data on migrant stocks, some studies also exploit the regional distribution of immigrants and look at the bilateral trade relationship between regions (or provinces) and foreign countries. ${ }^{4}$

Three main stylised facts emerge from the literature: (i) the trade-migration link appears stronger for differentiated goods than for homogeneous commodities; (ii) the effect of immigrants on imports is typically estimated to be larger than the one on exports; and (iii) there is ample evidence of a stronger pro-trade effect for high-skilled migrants.

1. The first stylised fact implies greater importance of ethnic networks in reducing information costs for more differentiated goods. This rather intuitive statement has been tested empirically mostly by dividing the spectrum of traded goods into three broad subclasses that differ with respect to the degree of differentiation according to the classification proposed by Rauch (1999). ${ }^{5}$ By running a gravity model separately for each aggregated group, Rauch and Trindade (2002) estimate separate elasticities of trade with

\footnotetext{
${ }^{4}$ Genc et al. (2012) analyse the distribution of immigration elasticities of imports and exports across 48 studies that yielded 300 observations: they report the meta-modal elasticities of immigrants which are, respectively, 0.12 for exports and 0.15 for imports. Among the main contributions on a single-country analysis of the protrade effect of immigrants we cite Dunlevy and Hutchinson (1999) for USA, Head and Ries (1998) for Canada, Tai (2009) for Switzerland and Girma and Yu (2002) for UK. The most important articles on a multicountry analysis are Felbermayr and Jung (2009), Egger et al. (2012), Felbermayr and Toubal (2012), Aleksynska and Peri (2014), Ehrhart et al. (2014). Lastly, the most influential papers that study the bilateral trade relationship between regions (or provinces) and foreign countries are Herander and Saavedra (2005) for USA, Wagner et al. (2002) for Canada, Bratti et al. (2014) for Italy, Peri and Requena-Silvente (2010) for Spain, Combes et al. (2005) and Briant et al. (2014) for France.

5 Peri and Requena-Silvente (2010) and Aleksynska and Peri (2014) use Broda and Weinstein (2006) classification to characterise the degree of differentiability of traded products according to their elasticity of substitution across varieties. Although Peri and Requena-Silvente (2010) and Aleksynska and Peri (2014) use a different classification of goods to characterise the degree of differentiability of products, they follow the same procedure of grouping these products into three broad categories: highly differentiated, moderately differentiated and less differentiated.
} 
respect to immigrant stocks for differentiated goods, goods traded on organised exchanges, and goods that display some reference price. Following Rauch (1999) and Rauch and Trindade (2002) products that possess references prices are deemed sufficiently homogeneous so that the price differential between two countries' markets conveys enough information - given customs and transport costs - on the profitability of shipping the product as opposed to buying the same commodity locally. On the contrary, commodities that do not possess reference prices are considered to be sufficiently differentiated so that prices cannot provide all the required information relevant for international trade: therefore, for those commodities, the role of transnational networks in overcoming informal barriers and attenuating frictions due to asymmetric information is likely to be much more prominent. Rauch and Trindade's (2002) statistics show that the pro-trade effect of ethnic networks on differentiated products is at least 24 per cent larger in magnitude compared to the correspondent impact on goods that exhibit some reference price and 60 per cent greater with respect to goods traded on organise exchanges. ${ }^{6}$ The same classification and a similar methodology have been used - among others - by Felbermayr and Toubal (2012) and Ehrhart et al. (2014).

2. As for the second stylised fact, the explanation of the gap between the immigrants elasticity of imports and exports is assumed to be the preference channel of migration. Bratti et al. (2014) summarise the results of a sample of some of the most influential contributions to the trade-migration literature and find a significant difference in magnitude. Furthermore, the meta-analysis proposed by Genc et al. (2012) - which is based on 48 studies and it contains about 300 estimates - indicates a discrepancy in the metamodal elasticity between imports and exports of approximately 0.03 . Given the lack of theoretical models which enable to separately identify the two channels, the gap in favour of the pro-import elasticity has commonly been the workaround strategy to determine the presence of the preference channel of migration. ${ }^{7}$ As Bratti et al. (2014) argue, this gap is commonly attributed 'by deductive reasoning' to a persistent difference in tastes between immigrants and natives.

3. Lastly, the third stylised fact indicates that the better the ability of the ethnic networks to receive and process information on trading opportunities, the higher the pro-trade effect. By focusing on a balanced panel of low-income Southern sending countries and high-income Northern receiving countries, Felbermayr and Jung (2009) find that the pro-trade elasticity of high-skilled workers is almost four times bigger than that of lowskilled workers when migration of all skill groups is accounted for. Other studies such as Herander and Saavedra (2005), Felbermayr and Toubal (2012) and Ehrhart et al. (2014) show higher pro-trade effects of high-skilled ethnic networks compared to the correspondent impact of the total stock of immigrants.

\footnotetext{
${ }^{6}$ This result refers to the effect of the variable 'CHINSHARE' in Rauch and Trindade (2002) - which proxies for the size of Chinese ethnic networks - on goods with reference price, goods traded in organised exchanges and differentiated products according to Rauch (1999) conservative classification estimated for the years 1980 and 1990. Similar results emerge for using the liberal classification.

${ }^{7}$ As Felbermayr et al. (2012) point out, a few papers - such as Felbermayr and Toubal (2012) - attempt to disentangle the transaction cost from the preference channel of migration. However, so far, according to Felbermayr et al. (2012), no conclusive answer to this identification problem is provided, and therefore, they suggest to leave this important question open.
} 


\section{b. North-South Quality Specialisation across Varieties}

Linder (1961) first predicted that quality plays a prominent role in the global pattern of trade. More recently, empirical work has provided evidence of the international specialisation in terms of quality within industries and product categories as a key determinant of the dynamics of North/South competition. We build on Fontagné et al. (2008) for summarising the three main stylised facts that emerge from the literature that are particularly useful for our analysis.

1. Vertical specialisation between North and South takes place within products across varieties: as showed by Hallak (2006), Fontagné et al. (2008), this evidence emerges only by studying bilateral trade relations at sufficiently level of disaggregation.

2. On the supply side, the unit value of exported products to a certain market varies with the level of development of the exporter. The model proposed by Falvey and Kierzkowski (1987) provides a first theoretical explanation of this empirical finding. They assume vertical product differentiation based on differences in quality of final products: since products of different quality have different factor intensities, countries well-endowed with skilled labour (or capital) will specialise in the more skill-intensive parts of the quality spectrum. Alternatively, this positive relationship can be explained by the exploitation of the productivity advantage of high-income economies to specialise in high-quality varieties (see Melitz 2000).

As confirmation of this stylised fact identified by Schott (2004), Fontagné et al. (2008), using BACI trade data set we summarise in Table 1 the mean of unit values for exports to the 19 OECD importers from an OECD and an Emerging Economies (EME) sample, respectively. The unit values for exports from highly developed economies on average are much higher; in addition, the difference between the top and the lowest quality segments (75th-100th and 0th-25th) is almost two times larger for OECD exports than it is for exports of emerging economies.

3. On the demand side, Fontagné et al. (2008) find that importers at different levels of development do consume a different bundle of varieties: rich countries tend to purchase and import more upmarket products, whereas developing economies import predominantly low-quality varieties. This stylised fact is in line with the prediction of the model proposed by Hallak (2006) where the role of quality in determining the trade pattern

TABLE 1

Variation of EUV by Exporters' Income per capita

\begin{tabular}{lcr}
\hline Sample & EME & OECD \\
& EUV (mean) & EUV (mean) \\
\hline Quality Segment $k$ & & \\
0-100th & 2207.6 & 3818.0 \\
0-25th & 7.95 & 11.5 \\
25th-50th & 26.1 & 35.5 \\
50th-75th & 58.8 & 82.9 \\
75th-100th & 8693.5 & 15095.1 \\
\hline
\end{tabular}

Notes:

(i) OECD data refer to trade flows from a selected sample of 23 OECD exporters to 19 OECD importers.

(ii) EME data refer to trade flows from a selected sample of 154 emerging economies to the same group of 19 OECD importers.

(iii) More details on the samples' composition are outlined in Appendix

(iv) The quality segments are defined by percentiles in each year according to the relative export unit values for each HS-6 digit product category. 
operates through the demand side depending on the relationship between income and quality choice. Similarly, in Flam and Helpman (1987) high-quality varieties are produced at higher costs reflected by higher prices, and marginal income is spent by consumers on quality rather than on quantity; Choi et al. (2006) build from the model of Flam and Helpman (1987), and they extend it to a multiproduct/multicountry setting allowing for high-income countries purchasing varieties of high quality.

\section{THE IMPACT OF MIGRATION ON BILATERAL TRADE}

We include our proxy for ethnic networks in a general gravity expression derived from a supply-side Ricardian model of trade à la Eaton and Kortum (2002) (henceforth EK). This is in contrast with the literature where, in general, ethnic networks as economic attractors are included within structural demand-side gravity equations derived from symmetric DixitStiglitz-Krugman monopolistic competition models, as Combes et al. (2005), Tai (2009), Felbermayr and Toubal (2012). ${ }^{8}$ In those models, the pro-trade effect of ethnic networks largely depends on the (proxies of) elasticity of substitution parameters: in Combes et al. (2005), Tai (2009) and Felbermayr and Toubal (2012), $\sigma$ is interacted with the ethnic networks coefficient to estimate the actual pro-trade impact of immigrants. For our purposes, this methodology is hard to implement since, to our knowledge, there are no data available in the literature for $\sigma$ at different quality levels. In addition, the use of proxies for $\sigma$ may create distortions in the resulting migration impact on trade. ${ }^{9}$ For these reasons, we consider the general gravity expression resulting from the Ricardian EK approach as better suited to address our research question. In our model, demand affects trade only through the allocation of spending across quality types, but within types, the share of each exporter in a country's imports does not depend on the elasticity of substitution, only on technologies. ${ }^{10}$

In what follows we derive an EK-type augmented gravity equation which builds on Fieler (2011) where goods of different quality may differ in demand and technology.

\section{a. The Underlying Theory: Extending Fieler (2011)}

The model builds on the Ricardian set-up of Eaton and Kortum (2002) and follows Fieler (2011) to characterise the demand side. On the supply side, the set-up reduces to the

\footnotetext{
${ }^{8}$ The differences between the two definitions of the gravity equation are well described in Head and Mayer (2014).

9 Tai (2009) focuses on the case of Switzerland, and it uses sector level elasticities of substitution based on the US elasticities estimated by Broda and Weinstein (2006): the choice of US values of $\sigma$ is motivated by the lack of data on the elasticities of substitution for each country and by the country's representability in the world economy. Following the discussion of available evidence in Anderson and Wincoop (2004), Felbermayr and Toubal (2012) assume that the elasticity is equal to six for aggregate trade, four for trade in differentiated goods and 25 for goods traded on organised exchanges (i.e. homogeneous goods).

${ }^{10}$ A minor advantage of the general EK gravity expression is that does not include GDP. Given the missing values of GDP for several countries in the CEPII database, the general EK gravity expression of the type $X_{n i}=G S_{i}$ $M_{n} \varphi_{n i}$ allows to utilise the whole database without the loss of any information. CEPII gravity database does not contain information on GDP for Afghanistan, Cuba, Iraq, Mongolia, São Tomé and Príncipe, Tuvalu, Myanmar and Somalia. The use of this functional form comes at no cost in terms of the unbiasedness of our ethnic networks' coefficients: as a robustness check in Appendix S1, we show that the elasticities of migrants are substantially unaffected by the inclusion of the GDP of country $i$ and country $n$ in our econometric specification.
} 
Ricardian EK framework. On the demand side, we depart from the standard EK model by abandoning the homothetic preferences assumption with constant elasticity of substitution. Based on the evidence that the income elasticity of demand varies across goods and that this variation is economically significant, Fieler (2011) divides goods into two types (A and B) which may differ in demand and technology. We extend Fieler (2011) by including a higher number of types: we assume that the number of types (and the correspondent elasticities of substitution) corresponds to the number of the quality segments $k$ that can be chosen arbitrarily. Indeed, products of different quality are likely to have different factor intensities and therefore different levels of technology (see Falvey and Kierzkowski 1987); at the same time, in line with Hallak (2006) we expect countries with higher average income to consume a larger proportion of high-quality products. For simplicity, we set $k=4$. This assumption allows to treat different levels of heterogeneity across goods in the model at a sufficiently small level of aggregation.

Without loss of generality, we consider a multisector economy where goods of quality $k$ of country $i$ produce a continuum of goods $j_{k} \in[0,1]$ with productivity $z_{i}\left(j_{k}\right)$. All consumers in the world choose the quantities of goods $j_{k}, Q\left(j_{k}\right)_{j_{k} \in[0,1]}$ to maximise the same utility function:

$$
U_{n}=\sum_{k=1}^{K}\left\{\alpha_{k}^{\frac{1}{\sigma_{k}}}\left[\int_{0}^{1} Q\left(j_{k}\right)^{\frac{\sigma_{k}-1}{\sigma_{k}}} d j_{k}\right]^{\frac{\sigma_{k}}{\sigma_{k}-1}}\right\},
$$

where $\alpha>0$ are weights and $\sigma_{k}>1(\forall k)$ is the elasticity of substitution across goods of the same quality and the income elasticity of demand for those goods. We normalise $\sum_{k=1}^{K} \alpha_{k}^{\frac{1}{\sigma_{k}}}=1$. The country $i$ 's productivity of goods of quality $k$ is a realisation of a random variable (drawn independently for each $j_{k}$ ) from its specific Fréchet probability distribution $F_{i}\left(j_{k}\right)=\exp ^{-T_{i} z^{-\theta_{k}}}$, where $\theta_{k}>1$ and $T_{i}>0$. The quality-specific parameter $\theta_{k}$ governs comparative advantage within quality segments, and it is common across countries: the larger the $\theta_{k}$, the smaller the variability in labour efficiencies across goods and countries. The assumption of linking the degree of heterogeneity of technology $\theta$ to quality level $k$ is justified by the empirical evidence. To check this, we consider US imports from a reduced sample of eight countries with similar characteristics concerning both transportation costs $d_{n i}$ and labour cost $w_{i}$, so that - in line with EK - delivering a unit from $i$ to $n$ will mostly depend on the technology parameter $z_{i}\left(j_{k}\right)$. We argue that these similar characteristics across exporters allow to consider the variation in EUV as a rough proxy for heterogeneity in labour efficiencies. In Table 2, we compare the standard deviation of export unit values (EUV) between the top and the low-quality segments using data from BACI data set. The quality segment $k$ are defined by percentiles in each year according to the relative export unit values for each HS-6 digit sector. The statistics indicate that heterogeneity of export unit values is much larger for top-quality segments, suggesting an inverse relationship between $\theta_{k}$ and quality. In addition, the spread between low and top-quality segments rises as we move towards the tail of the distribution, that is passing from $k=2$ to $k=4$.

$T_{i}$ governs the location of the distribution and reflects country $i$ 's absolute advantage: a bigger $T_{i}$ indicates that a higher efficiency draw for any good $j$ is more likely. We assume that $T_{i}$ does not depend on quality $k$, which implies that a country that is generally efficient at making goods of quality $k$ is also efficient at making goods of all qualities.

Having drawn a particular productivity level and assuming wage as the only input cost, that is $c_{i}=w_{i}$, the cost of producing a unit of $\operatorname{good} j$ in country $i$ of quality $k$ is $w_{i} / z_{i}\left(j_{k}\right)$. 
TABLE 2

Heterogeneity of Export Unit Values: low vs high Quality

\begin{tabular}{|c|c|c|c|c|c|}
\hline \multirow{2}{*}{$\begin{array}{l}\text { Quality } \\
k\end{array}$} & \multicolumn{2}{|l|}{ Low } & \multicolumn{3}{|l|}{ High } \\
\hline & Perc. & $S D$ & Perc. & & $S D$ \\
\hline$k=2$ & $0-50$ th & 1.83 & 50th-100th & & 2.13 \\
\hline$k=3$ & $0-33$ th & 1.83 & 66th-100th & & 2.20 \\
\hline$k=4$ & $0-25$ th & 1.84 & 75th-100th & & 2.27 \\
\hline Exporter & & $\begin{array}{l}\text { Distance } \\
\text { Km }\end{array}$ & & $\begin{array}{l}\text { Labour } \\
\text { US\$ }\end{array}$ & Cost \\
\hline Austria & & 8,343 & & 24.91 & \\
\hline Belgium & & 7,553 & & 28.92 & \\
\hline Denmark & & 7,487 & & 23.70 & \\
\hline France & & 7,665 & & 24.86 & \\
\hline Germany & & 7,861 & & 29.16 & \\
\hline Norway & & 7,186 & & 25.83 & \\
\hline Sweden & & 7,667 & & 25.83 & \\
\hline Switzerland & & 8,010 & & 30.42 & \\
\hline
\end{tabular}

Notes:

(i) Data of the upper part are expressed in log of export unit values.

(ii) The data refer to the standard deviation of EUV in the tails of the quality distribution.

(iii) Trade flows are from a selected sample of eight OECD exporters to United States.

(iv) The lower part shows: (i) the distance expressed in $\mathrm{km}$ between USA and every exporter country and (ii) the hourly compensation per worker in the manufacturing for year 1997.

(v) Data on compensations are from the US Bureau of Labor Statistics.

(vi) Quality segments $k$ are defined by percentiles in each year according to the relative export unit values for each HS-6 digit product category.

With the assumption of perfect competition, Samuelson iceberg trade costs and triangle inequality, the price of a good imported from country $i$ into country $n$ is the unit production cost multiplied by the geographic barriers:

$$
p_{n i}\left(j_{k}\right)=\frac{d_{n i} w_{i}}{z_{i}\left(j_{k}\right)} .
$$

Substituting equation (2) into the distribution of efficiency $F_{i}\left(j_{k}\right)$ implies that country $i$ presents country $n$ with a distribution of prices $G_{n i}\left(p_{k}\right)=1-\exp ^{-\left[T_{i}\left(d_{n i} w_{i}\right)^{-\theta_{k}}\right] p_{k}^{\theta_{k}}}$. As Fieler (2011) pointed out, the Fréchet distribution gives a dual role to type or quality or specific trade elasticity $\theta_{k}$.

1. First, the variability of technology across commodities governs comparative advantage within quality segments. A smaller $\theta_{k}$, indicating more heterogeneity across goods within quality segment $k$ (hence a greater dispersion in price distribution), exerts a stronger force for trade against the resistance imposed by the geographic barriers $d_{n i}$, that is, in each quality segment $k$, the smaller $\theta_{k}$ the higher the level of trade.

2. Second, the variability of labour efficiencies across countries governs comparative advantage across types $k$. Therefore, $\theta_{k}$ determines also international specialisation across quality segments and it links this model to the stylised facts outlined in Section $2 b$. As in Fieler (2011), we take the mean of the Fréchet distribution to clarify this point. Indeed, the cost of delivering one unit of good $j_{k}$ from country $i$ to country $n$ relative to the 
cost of producing it domestically is $\left(p_{n i j_{(k)}} / p_{n i j_{(k)}}\right)=\left(z_{n j_{(k)}} / z_{i j_{(k)}}\right)\left(d_{n i} w_{i} / w_{n}\right)$. By taking the expectation over $j_{k}$ the expression reduces to:

$$
\frac{E\left(p_{\left.n i j_{(k)}\right)}\right)}{E\left(p_{n n j_{(k)}}\right)}=\left(\frac{T_{i}}{T_{n}}\right)^{\frac{1}{\theta_{k}}} \frac{d_{n i} w_{i}}{w_{n}} .
$$

As $\theta_{k}$ increases, the term $\left(T_{i} / T_{n}\right)^{1 / \theta_{k}}$ approaches 1 and the term $d_{n i} w_{i} / w_{n}$ outweighs the ratio of technology parameters $\left(T_{i} / T_{n}\right)$ in determining costs. By combining this equation with the inverse relationship between $\theta_{k}$ and quality level that emerges from Table 2, we can predict the international specialisation across quality segments in line with the findings of Schott (2004), Fontagné et al. (2008):

Developing countries will tend to specialise into low-quality segments - where $\theta_{k}$ is high because they are characterised by relatively low wages. By the same token, developed economies specialise in high-quality segments where $\theta_{k}$ is small because on average these are the countries characterised by high level of efficiencies (large $T_{i}$ 's). Lastly, equation (3) illustrates the Alchian-Allen conjecture: for a give value of relative wage $w_{i} / w_{n}$, low-quality segments are relatively more sensitive to variation in international transaction costs.

Given these assumptions and following the standard EK derivation, we get the gravity expression which is re-expressed as the imports of country $n$ 's from country $i$ relative to its domestic consumption:

$$
\frac{X_{n i}^{k}}{X_{n n}^{k}}=\frac{T_{i}}{T_{n}}\left(\frac{d_{n i} w_{i}}{w_{n}}\right)^{-\theta_{k}} .
$$

Equation (4) can be simplified in $\log$ term to $\ln X_{n i}^{k}=S_{i}-S_{n}-\theta_{k} \ln d_{n i}$, where $S_{i}$ stands for the competitiveness of country $i$, which is function of technology and unit production

\section{b. Econometric Specification and Empirical Strategy}

Migration enters the Ricardian EK model by affecting the distribution of prices $G_{n i}\left(p_{k}\right)$ that country $i$ presents to country $n$. Migrants' networks mitigate the negative effect of geographic barriers by attenuating incomplete and asymmetric information in international transactions. ${ }^{11}$ This is a comparative advantage effect since it impacts directly the level of heterogeneity across goods and countries through the parameter $\theta_{k}$. However, this positive effect of ethnic

\footnotetext{
${ }^{11}$ It is important to recall that our research question is to estimate the trade cost channel of migration which is based solely on the size of ethnic networks: we are looking at the qualitative side of the protrade effect of immigrants who are assumed to boost trade only by reducing transaction costs. By relaxing the Ricardian assumption of immobility of workers across countries, migrants may also affect international trade quantitatively, that is through a variation in wages due to the change in the relative size of countries. However, the data indicate that despite the number of migrants is currently increasing, it does not significantly alter the countries' labor endowments in relative terms (migrants are approximately 3 per cent of world's population). Given the migrants' impact on country's relative size is quantitatively small, we focus on ethnic networks' qualitative effect on trade and we maintain the standard Ricardian immobility of factors assumption. For a discussion on the channels through which migrants may affect trade and the effect of ethnic networks on the estimation of trade cost elasticity parameter in a Ricardian Model à la EK see Lanati (2014).
} 
networks on trade - which is proportional to the stocks of bilateral migration between country $i$ and country $n-$ is likely to vary across quality segments $k$. Indeed, the relationship between product quality and pro-trade elasticity of ethnic networks is subject to contrasting forces:

- On the one hand, being differentiated commodities - those whose prices cannot convey all the information relevant for international trade (see Rauch and Trindade 2002) - concentrated more into high-quality products, migrants may have larger effects on top-quality segments.

- On the other hand, low-quality varieties may be slightly more sensitive than high price ones to transaction costs (Alchian-Allen conjecture), and therefore, the informative role of ethnic networks may be larger for low-quality ranges. More formally, assuming $\theta_{k}$ and quality level are inversely related, the impact of the determinants of trade costs $d_{n i}$, including the impact of migrants (other things constant) on $\left(p_{n i j_{(k)}}\right) /\left(p_{n i j_{(k)}}\right)$, may be larger for low-quality varieties (see equation 3).

- Alternatively, the trend of the pro-trade effect of immigrants over quality might be driven by the North-South specialisation across varieties for both supply and demand. More specifically, ethnic networks may mostly facilitate imports of those varieties for which their countries of origin have a comparative advantage. As for exports, ethnic networks can be more effective in promoting exports to their homeland of those varieties for which there is relatively higher demand.

Which of these effects will prevail is a matter for empirical analysis.

In order to capture the trade cost channel of migration, we divide $d_{n i}$ into two components. The first term is the usual EK geographic barriers term which is denoted with $\rho$, the second one is the information costs $I_{n i}$ which in this model will depend solely (negatively) on migrants' networks. For every if $=n, d_{n i}$ is defined as follows:

$$
d_{n i}=\left[\rho_{n i} I_{n i}\right] .
$$

As in EK geographic barriers take the following multiplicative form $\rho_{n i}=$ dist $_{n i} \exp ^{\left[{ }^{[a n g} g_{n i} a d j_{n i} R T A_{n i}\right]}$, whereas informational frictions $I_{n i}$ are only affected by migrants' networks as follows: $I_{n i}=1 / \mathrm{mig}_{n i}{ }^{12}$

More precisely, mig $_{n i}$ is the total number of migrants born in country $i$ resident in country $n$. By combining equations (2) and (5), the price of a good imported from country $i$ into country $n$ then becomes: $p_{n i}\left(j_{k}\right)=w_{i} I_{n i} \rho_{n i} / z_{i}\left(j_{k}\right)$. By substituting this expression into the distribution of efficiency $F_{i} j(k)$ and by following the same procedure as in the previous section we get $\left(X_{n i}^{k} / X_{n n}^{k}\right)=\left(T_{i} / T_{n}\right)\left(\rho_{n i} w_{i} / m_{13} g_{n i} w_{n}\right)^{-\theta_{k}}$, from which we obtain the following empirical specification:

$$
X_{n i, g, t}^{k}=f\left(S, \text { dist }_{n i}, \text { lang }_{n i}, \operatorname{adj}_{n i}, R T A_{n i, t}, \operatorname{mig}_{n i, t}\right)+\delta_{n i, g, t}^{k},
$$

\footnotetext{
12 This expression follows Combes et al. (2005). However, Combes et al. (2005) include plant as an additional determinant of $I_{n i}$.

${ }^{13}$ Equation (6) incorporates the trade cost channel of migration in a supply-side derivation of the gravity expression. Unlike Combes et al. (2005), Tai (2009), Felbermayr and Toubal (2012) and all the demand-side gravity equations derived from symmetric Dixit-Stiglitz-Krugman monopolistic competition models, the assumptions behind the Ricardian EK model automatically rule out the preference channel of migration and any role of the elasticity of substitution in determining immigrants' trade effect (for further discussion on this issue see a very early version of this paper Giovannetti and Lanati 2014).
} 
for $k=1,2 \cdots K . X_{n i, g, t}^{k}$ stands for imports of country $n$ from country $i$ of HS-6 digit sector $g$ of quality at time $t . S$ stands for the comprehensive set of fixed effects included in the specification, namely exporter $S_{i}$, importer $S n$, sector $S_{g}$ and year $S_{t}$ dummies, respectively. ${ }^{14}$ dist $_{n i}$ is the distance between importer and exporter; lang $_{n i}$, contig ${ }_{n i}$ and $R T A_{n i, t}$ are dummies which equal 1 if country $i$ and country $n$ share a common language, have a common border and both belong to a regional trade agreement at time $t$. mig $_{n i, t}$ is the stock of immigrants resident in country $n$ and born in country $i$ at time $t$. $\delta_{n i, g, t}^{k}$ is the error term. These variables proxy trade barriers. The implicit hypothesis is that transport costs increase with distance, are lower between country-pairs that share a common border and/or speak a common language and are lower for country-pairs which both belong to a regional trade agreement. ${ }^{15}$ The empirical strategy is similar to Rauch and Trindade (2002) who divide traded commodities into three groups and estimate the gravity model separately for each aggregated group based on the level of product differentiation. Similarly, we classify traded goods according to their quality level $k$ and we separately estimate pro-trade elasticity of ethnic networks for each subgroup. We utilise one of the two classifications of quality based on the differences of traded goods in terms of unit values proposed by Fontagné et al. (2008). As in Hallak (2006), we assume that all cross-country variation in unit values can be attributed to differences in quality. Since unit value is the ratio between the value and the quantity of exports, observations with zero trade flows and zero or no quantities are automatically dropped. Despite this loss of information, we are able to estimate consistently the pro-trade effect of immigrants using a very large number of observations. ${ }^{16}$ Furthermore, the lack of zero trade flows in our dependent variable allows us to avoid the issue of treatment of zeroes in gravity log-log specifications as warned by Santos Silva and Tenreyro (2006) and Head and Mayer (2014).

Following the alternative methodology proposed by Fontagné et al. (2008), market segments are simply defined by percentiles in each year. We define the relative unit value ratio for any trade flow $s: r=\left(U V_{s} / U V_{\text {World }}\right)$, where the reference group is the trade-weighted average of $U V$ over all flows in the world of a given HS-6digit category. ${ }^{17}$ This classification of unit values of imported and exported varieties adapts rather well to the Ricardian model à la EK outlined in Section 3a characterised by a continuum of products $j$ vertically differentiated according to their quality level $k$ : we use data at six-digit level which encompass different traded commodities under the same HS6

\footnotetext{
${ }^{14}$ As suggested by the referee and exploiting the fact the structural gravity specification is at product level, we replicate the empirical analysis by augmenting equation 6 with importer and exporter dummies interacted with product and time fixed effects. The underlying idea is that equation 6 imposes the very strong assumption that all countries have the same specialisation $S_{i}$ and the same distribution of preferences $S_{n}$ across products (HS 6-digit) $S_{g}$. In other words, equation 6 may not fully control for the exporter comparative advantage $S_{i g t}$ or for product preferences in the destination market $S_{n g t}$. In line with Costinot et al. (2012), another reason why it would be important to include $S_{i g t}$ is that exporter-sector fixed effects control for all exporter-sector-specific factors that make the country more productive in a given sector. The results of the augmented model estimated with $S_{i g t}$ and $S_{n g t}$ are reported in Tables 3 and 4.

15 Equation 6 includes the $t$ subscript as in Felbermayr and Jung (2009) who estimate a very similar model with pooled OLS. For simplicity in what follows we will drop the $t$ subscript in the text from the time-varying variables.

${ }_{16}$ A detailed description of the data needed for the estimations is outlined in the Appendix.

17 The reference group is defined as the weighted average of UV over all flows in the world of a given HS- 6 digit category using traded quantities as weights: $U V_{\text {World }}=\Sigma i\left(U V_{i} \times Q_{i} / Q_{\text {World }}\right)$, where $Q_{\text {World }}$ is the sum of all the available traded quantities of a given HS-6 digit category in a given year. Note that since we are considering classes defined by percentiles in each year, the definition $U V_{\text {World }}$ does not have any effect on the distribution of $U V$. We are using this definition to better reconcile this procedure with the methodology adopted in the seminal work of Fontagné et al. (2008) that is presented in Appendix S1 as robustness check.
} 
TABLE 3

Gravity Equation Augmented with $S_{i g t}$ and $S_{n g t}$

\begin{tabular}{|c|c|c|c|c|c|c|}
\hline $\begin{array}{l}\text { Sample } \\
\text { Skill Level }\end{array}$ & $\begin{array}{l}\text { Whole } \\
\text { Tot }\end{array}$ & $\begin{array}{l}\text { Whole } \\
\text { High }\end{array}$ & $\begin{array}{l}\text { OECD } \\
\text { Tot }\end{array}$ & $\begin{array}{l}\text { OECD } \\
\text { High }\end{array}$ & $\begin{array}{l}\text { EME } \\
\text { Tot }\end{array}$ & $\begin{array}{l}\text { EME } \\
\text { High }\end{array}$ \\
\hline Dependent Variable & $\ln X_{n i, g}^{k}$ & $\ln X_{n i, g}^{k}$ & $\ln X_{n i, g}^{k}$ & $\ln X_{n i, g}^{k}$ & $\ln X_{n i, g}^{k}$ & $\ln X_{n i, g}^{k}$ \\
\hline Estimator & $2 W F E$ & $2 W F E$ & $2 W F E$ & $2 W F E$ & $2 W F E$ & $2 W F E$ \\
\hline \multicolumn{7}{|l|}{ Imports } \\
\hline $\operatorname{lnmig}_{n i}$ & $\begin{array}{c}0.091 * \\
(0.012)\end{array}$ & $\begin{array}{c}0.106^{*} \\
(0.015)\end{array}$ & $\begin{array}{c}0.158^{*} \\
(0.027)\end{array}$ & $\begin{array}{c}0.207^{*} \\
(0.031)\end{array}$ & $\begin{array}{c}0.070 * \\
(0.012)\end{array}$ & $\begin{array}{c}0.081 * \\
(0.014)\end{array}$ \\
\hline lndist $_{n i}$ & $\begin{array}{c}-0.673^{*} \\
(0.053)\end{array}$ & $\begin{array}{c}-0.662 * \\
(0.052)\end{array}$ & $\begin{array}{c}-0.731^{*} \\
(0.102)\end{array}$ & $\begin{array}{c}-0.700^{*} \\
(0.098)\end{array}$ & $\begin{array}{c}-0.766^{*} \\
(0.050)\end{array}$ & $\begin{array}{r}-0.758 * \\
(0.049)\end{array}$ \\
\hline contig $_{n i}$ & $\begin{array}{c}0.649 * \\
(0.096)\end{array}$ & $\begin{array}{c}0.674 * \\
(0.096)\end{array}$ & $\begin{array}{c}0.520^{*} \\
(0.115)\end{array}$ & $\begin{array}{c}0.543^{*} \\
(0.114)\end{array}$ & $\begin{array}{c}0.630 * \\
(0.187)\end{array}$ & $\begin{array}{r}0.638^{*} \\
(0.191)\end{array}$ \\
\hline $\operatorname{lang}_{n i}$ & $\begin{array}{c}0.292^{*} \\
(0.068)\end{array}$ & $\begin{array}{c}0.269 * \\
(0.069)\end{array}$ & $\begin{array}{c}0.274^{*} \\
(0.100)\end{array}$ & $\begin{array}{c}0.225^{*} \\
(0.102)\end{array}$ & $\begin{array}{c}0.214^{*} \\
(0.075)\end{array}$ & $\begin{array}{c}0.182 * \\
(0.079)\end{array}$ \\
\hline$r t a_{n i}$ & $\begin{array}{c}0.517 * \\
(0.117)\end{array}$ & $\begin{array}{l}0.520^{*} \\
(0.118)\end{array}$ & $\begin{array}{c}0.586^{*} \\
(0.221)\end{array}$ & $\begin{array}{c}0.606^{*} \\
(0.220)\end{array}$ & $\begin{array}{c}0.315^{*} \\
(0.095)\end{array}$ & $\begin{array}{r}0.332 * \\
(0.099)\end{array}$ \\
\hline$R^{2}$ & 0.708 & 0.708 & 0.729 & 0.730 & 0.729 & 0.729 \\
\hline \multicolumn{7}{|l|}{ Exports } \\
\hline $\operatorname{lnmig}_{n i}$ & $\begin{array}{c}0.098^{*} \\
(0.012)\end{array}$ & $\begin{array}{c}0.119^{*} \\
(0.014)\end{array}$ & $\begin{array}{c}0.197 * \\
(0.027)\end{array}$ & $\begin{array}{c}0.254^{*} \\
(0.030)\end{array}$ & $\begin{array}{c}0.086^{*} \\
(0.014)\end{array}$ & $\begin{array}{c}0.104 * \\
(0.018)\end{array}$ \\
\hline lndist $_{n i}$ & $\begin{array}{c}-0.886^{*} \\
(0.040)\end{array}$ & $\begin{array}{c}-0.875^{*} \\
(0.040)\end{array}$ & $\begin{array}{c}-0.659 * \\
(0.094)\end{array}$ & $\begin{array}{c}-0.641^{*} \\
(0.088)\end{array}$ & $\begin{array}{c}-0.855^{*} \\
(0.047)\end{array}$ & $\begin{array}{r}-0.849 * \\
(0.046)\end{array}$ \\
\hline contig $_{n i}$ & $\begin{array}{c}0.555^{*} \\
(0.093)\end{array}$ & $\begin{array}{c}0.573 * \\
(0.094)\end{array}$ & $\begin{array}{c}0.563^{*} \\
(0.107)\end{array}$ & $\begin{array}{c}0.579 * \\
(0.104)\end{array}$ & $\begin{array}{c}0.592^{*} \\
(0.177)\end{array}$ & $\begin{array}{r}0.598^{*} \\
(0.181)\end{array}$ \\
\hline lang $_{n i}$ & $\begin{array}{c}0.352 * \\
(0.061)\end{array}$ & $\begin{array}{c}0.318^{*} \\
(0.063)\end{array}$ & $\begin{array}{c}0.210 * \\
(0.092)\end{array}$ & $\begin{array}{c}0.156 \\
(0.094)\end{array}$ & $\begin{array}{c}0.419 * \\
(0.066)\end{array}$ & $\begin{array}{c}0.379 * \\
(0.072)\end{array}$ \\
\hline$r t a_{n i}$ & $\begin{array}{c}0.039 \\
(0.108)\end{array}$ & $\begin{array}{c}0.042 \\
(0.108)\end{array}$ & $\begin{array}{c}0.675^{*} \\
(0.183)\end{array}$ & $\begin{array}{l}0.670^{*} \\
(0.175)\end{array}$ & $\begin{array}{c}0.088 \\
(0.113)\end{array}$ & $\begin{array}{c}0.107 \\
(0.118)\end{array}$ \\
\hline$R^{2}$ & 0.688 & 0.689 & 0.731 & 0.731 & 0.677 & 0.677 \\
\hline
\end{tabular}

Network Effect By Quality Segment

Imports

\begin{tabular}{lcccccc}
\hline Quality Segment $k$ & lnmig $_{n i}$ & lnmig $_{n i}$ & lnmig $_{n i}$ & $\operatorname{lnmig}_{n i}$ & $\operatorname{lnmig}_{n i}$ & $\operatorname{lnmig}_{n i}$ \\
\hline \multirow{4}{*}{ 0-25th } & & & & & & \\
& $0.082^{*}$ & $0.092^{*}$ & $0.143^{*}$ & $0.185^{*}$ & $0.073^{*}$ & $0.079^{*}$ \\
25th-50th & $(0.012)$ & $(0.016)$ & $(0.026)$ & $(0.031)$ & $(0.015)$ & $(0.020)$ \\
& $0.116^{*}$ & $0.137^{*}$ & $0.191^{*}$ & $0.249^{*}$ & $0.089^{*}$ & $0.104^{*}$ \\
50th-75th & $(0.014)$ & $(0.017)$ & $(0.028)$ & $(0.033)$ & $(0.015)$ & $(0.017)$ \\
& $0.124^{*}$ & $0.150^{*}$ & $0.201^{*}$ & $0.259^{*}$ & $0.078^{*}$ & $0.097^{*}$ \\
75th-100th & $(0.017)$ & $(0.020)$ & $(0.030)$ & $(0.035)$ & $(0.016)$ & $(0.019)$ \\
& $0.102^{*}$ & $0.121^{*}$ & $0.192^{*}$ & $0.234^{*}$ & $0.060^{*}$ & $0.069^{*}$ \\
& $(0.019)$ & $(0.023)$ & $(0.032)$ & $(0.037)$ & $(0.024)$ & $(0.030)$ \\
\hline
\end{tabular}


TABLE 3 Continued

Network Effect By Quality Segment

\begin{tabular}{lcccccc}
\hline Exports & \multicolumn{7}{c}{} \\
\hline Quality Segment $k$ & lnmig $_{n i}$ & lnmig $_{n i}$ & lnmig $_{n i}$ & $\operatorname{lnmig}_{n i}$ & $\operatorname{lnmig}_{n i}$ & $\operatorname{lnmig}_{n i}$ \\
\hline \multirow{2}{*}{ 0-25th } & $0.091^{*}$ & $0.108^{*}$ & $0.163^{*}$ & $0.217^{*}$ & $0.086^{*}$ & $0.102^{*}$ \\
& $(0.013)$ & $(0.017)$ & $(0.029)$ & $(0.032)$ & $(0.018)$ & $(0.023)$ \\
25th-50th & $0.122^{*}$ & $0.146^{*}$ & $0.236^{*}$ & $0.303^{*}$ & $0.095^{*}$ & $0.115^{*}$ \\
& $(0.014)$ & $(0.017)$ & $(0.030)$ & $(0.033)$ & $(0.018)$ & $(0.022)$ \\
50th-75th & $0.115^{*}$ & $0.140^{*}$ & $0.248^{*}$ & $0.313^{*}$ & $0.091^{*}$ & $0.111^{*}$ \\
& $(0.016)$ & $(0.020)$ & $(0.029)$ & $(0.033)$ & $(0.019)$ & $(0.023)$ \\
75th-100th & $0.087^{*}$ & $0.109^{*}$ & $0.203^{*}$ & $0.260^{*}$ & $0.074^{*}$ & $0.093^{*}$ \\
& $(0.013)$ & $(0.016)$ & $(0.032)$ & $(0.036)$ & $(0.016)$ & $(0.019)$ \\
\hline Imp*HS-6*Year FE & $\mathrm{X}$ & $\mathrm{X}$ & $\mathrm{X}$ & $\mathrm{X}$ & $\mathrm{X}$ & $\mathrm{X}$ \\
Exp*HS-6*Year FE & $\mathrm{X}$ & $\mathrm{X}$ & $\mathrm{X}$ & $\mathrm{X}$ & $\mathrm{X}$ & $\mathrm{X}$ \\
\hline
\end{tabular}

Notes:

(i) The upper part of the table reports the dyadic effects of the gravity specification for the Whole, EME and OECD samples, respectively.

(ii) The lower part shows the pro-trade effects of immigrants on products of different quality $k$.

(iii) Samples are divided into classes (based on quartiles) according to the degree of quality of traded products.

(iv) The number of observations for each quality segment in the upper part is approximately one-quarter of the total number of observations.

(v) The gravity equations are estimated adding Exporter $\times$ Sector $\times$ Year $S_{\text {igt }}$ and Importer $\times$ Sector $\times$ Time $S_{n g t}$ Fixed Effects.

(vi) The estimated equation is therefore $\ln X_{n i, g, t}^{k}=S_{i g t}-S_{n g t}-\theta_{k}$ lndist $_{n i}-\theta_{k}$ lang $_{n i}-\theta_{k} R_{\text {TA }} A_{n i, t}-\theta_{k}$ contig $_{n i}$ $+\theta_{k}$ lnmig $_{n i, t}+\theta_{k} \delta_{n i, g, t}^{k}$

(vii) For exports, the destination country $\mathrm{n}$ stands for the exporting country.

(viii) The coefficients are obtained with 2WFE using the HD Fixed Effects Stata command reg2hdfe provided by Guimaraes and Portugal (2010).

(ix) Detailed information on number of observations, $R^{2}$ and first-stage coefficients for each regression is reported in Table 4.

(x) Standard errors in parenthesis are clustered by trading-pair.

(xi) * Statistically significant at $5 \%$.

category, reported by firms in a given country at time $t .{ }^{18}$ Given the possibility of some selection bias due to the relatively small size of the subgroups - that is some country-pairs may appear solely in some specific quality classes and not in others - the spectrum of traded goods based on $r$ is

${ }^{18}$ As in Fontagné et al. (2008), we utilise trade data from BACI data set of CEPII to calculate unit values. BACI is constructed using a procedure that reconciles the declarations of the exporter and the importer starting from the data provided by the United Nations Statistical Division (COMTRADE database). As correctly pointed out by the referee, one of the possible issues with BACI data set is the quality of COMTRADE data on quantity: when value is available missing quantities are estimated using a unique standard unit value defined at the World level which could remove most of the variation in prices across countries. Since BACI is derived from the same data, it shares this limitation. To address this issue as robustness check, we replicate the same analysis using the trade unit values (TUV) data set of CEPII. As we will see later, the results show the same trend over quality and our main conclusions stand. Further information on the pros and cons of using TUV data set and the methodology implemented are included in the Appendix 
TABLE 4

Gravity Equation Augmented with $S_{i g t}$ and $S_{n g t}-$ Gravity Coefficients

\begin{tabular}{|c|c|c|c|c|}
\hline Dependent Variable & $\ln X_{n i, g}^{k}$ & $\ln X_{n i, g}^{k}$ & $\ln X_{n i, g}^{k}$ & $\ln X_{n i, g}^{k}$ \\
\hline Estimator & $2 W F E$ & $2 W F E$ & $2 W F E$ & $2 W F E$ \\
\hline \multicolumn{5}{|c|}{ Exports } \\
\hline Whole & $0-25$ th & 25 th-50th & $50 t h-75$ th & 75 th-100th \\
\hline lndist $_{n i}$ & $-0.985^{*}$ & $-1.023^{*}$ & $-0.943^{*}$ & $-0.819^{*}$ \\
\hline$r t a_{n i}$ & -0.004 & 0.004 & 0.019 & 0.082 \\
\hline lang $_{n i}$ & $0.415^{*}$ & $0.470^{*}$ & $0.424 *$ & $0.253 *$ \\
\hline contig $_{n i}$ & $0.658^{*}$ & $0.470^{*}$ & $0.467 *$ & $0.500^{*}$ \\
\hline$R^{2}$ & 0.863 & 0.880 & 0.875 & 0.842 \\
\hline Obs. & 979,111 & 974,127 & 971,703 & 976,619 \\
\hline \multicolumn{5}{|l|}{ OECD } \\
\hline lndist $_{n i}$ & $-0.880^{*}$ & $-0.784 *$ & $-0.668^{*}$ & $-0.476^{*}$ \\
\hline$r t a_{n i}$ & $0.470 *$ & $0.624 *$ & $0.748^{*}$ & $0.952 *$ \\
\hline $\operatorname{lang}_{n i}$ & $0.317^{*}$ & $0.338^{*}$ & $0.290 *$ & $0.194 *$ \\
\hline contig $_{n i}$ & $0.570^{*}$ & $0.440 *$ & $0.418^{*}$ & $0.476^{*}$ \\
\hline$R^{2}$ & 0.897 & 0.918 & 0.916 & 0.890 \\
\hline Obs. & 370,283 & 365,347 & 362,946 & 367,842 \\
\hline \multicolumn{5}{|l|}{ EME } \\
\hline lndist $_{n i}$ & $-0.995^{*}$ & $-1.101 *$ & $-0.968 *$ & $-0.751 *$ \\
\hline$r t a_{n i}$ & 0.007 & -0.011 & -0.015 & 0.142 \\
\hline lang $_{n i}$ & $0.468^{*}$ & $0.634 *$ & $0.553^{*}$ & $0.288 *$ \\
\hline contig $_{n i}$ & $0.753^{*}$ & $0.590 *$ & $0.592 *$ & $0.760 *$ \\
\hline$R^{2}$ & 0.880 & 0.893 & 0.889 & 0.867 \\
\hline Obs. & 612,529 & 607,505 & 605,124 & 609,984 \\
\hline \multicolumn{5}{|c|}{ Imports } \\
\hline Whole & $0-25$ th & $25 t h-50 t h$ & $50 t h-75$ th & 75 th-100th \\
\hline lndist $_{n i}$ & $-0.688 *$ & $-0.783 *$ & $-0.745^{*}$ & $-0.670 *$ \\
\hline$r t a_{n i}$ & $0.507 *$ & $0.525^{*}$ & $0.501 *$ & $0.529 *$ \\
\hline $\operatorname{lang}_{n i}$ & $0.244 *$ & $0.369 *$ & $0.383^{*}$ & $0.232 *$ \\
\hline contig $_{n i}$ & $0.744^{*}$ & $0.585^{*}$ & $0.526^{*}$ & $0.560^{*}$ \\
\hline$R^{2}$ & 0.861 & 0.886 & 0.883 & 0.856 \\
\hline Obs. & 624,525 & 619,514 & 617,075 & 622,070 \\
\hline \multicolumn{5}{|l|}{ OECD } \\
\hline lndist $_{n i}$ & $-0.946^{*}$ & $-0.882 *$ & $-0.718 *$ & $-0.507 *$ \\
\hline$r t a_{n i}$ & $0.425^{*}$ & $0.504 *$ & $0.648 *$ & $0.893^{*}$ \\
\hline lang $_{n i}$ & $0.345^{*}$ & $0.371^{*}$ & $0.370^{*}$ & $0.205^{*}$ \\
\hline contig $_{n i}$ & $0.481^{*}$ & $0.394 *$ & $0.382 *$ & $0.440^{*}$ \\
\hline$R^{2}$ & 0.896 & 0.914 & 0.911 & 0.885 \\
\hline Obs. & 377,398 & 372,514 & 370,069 & 374,903 \\
\hline
\end{tabular}


TABLE 4 Continued

\begin{tabular}{lcccr}
\hline Dependent Variable & $\ln X_{n i, g}^{k}$ & $\ln X_{n i, g}^{k}$ & $\ln X_{n i, g}^{k}$ & $\ln X_{n i, g}^{k}$ \\
\hline Estimator & $2 W F E$ & $2 W F E$ & $2 W F E$ \\
\hline Whole & & Exports & & \\
\hline EME & $0-25 t h$ & 25 th-50th & 50 th-75th & 75 th-100th \\
lndist $_{n i}$ & & & & \\
rta $_{n i}$ & $-0.881^{*}$ & $-1.01^{*}$ & $-0.956^{*}$ & $-0.814^{*}$ \\
lang $_{n i}$ & $0.336^{*}$ & $0.343^{*}$ & $0.357^{*}$ & $0.343^{*}$ \\
contig $_{n i}$ & 0.160 & $0.289^{*}$ & $0.357^{*}$ & 0.180 \\
$R^{2}$ & $0.799^{*}$ & $0.507^{*}$ & $0.465^{*}$ & $0.508^{*}$ \\
Obs. & 0.911 & 0.924 & 0.920 & 0.911 \\
\hline
\end{tabular}

Notes:

(i) Estimates obtained with clustered by trading-pair standard errors.

(ii) The table reports all the gravity coefficients of equation (6) other than lnmigni for each sample and quality segment.

(iii) The estimated gravity equations are augmented with Exporter*Sector*Year $S_{i g t}$ and Importer*Sector*Year Fixed Effects.

(iv) The estimates refer to the regressions with the total stock of immigrants as variable of interest.

(v) The coefficients are obtained with 2WFE using the HD Fixed effects Stata command reg2hdfe provided by Guimaraes and Portugal (2010).

(vi) * Statistically significant at $5 \%$.

divided into quartiles $(K=4)$ : the downmarket segment lies under the 25th percentile, whereas the upmarket segment above the 75th percentile, in between the other two intermediate classes. ${ }^{19}$

Our empirical strategy initially departs from the assumption of a common Theta which imposes for each quality segment the same variation in productivity (or the same incentive to trade) across countries characterised by different levels of GDP per capita. ${ }^{20}$ We first let the degree of heterogeneity in efficiencies for each $k$ to diverge between OECD and non-OECD trade partners by considering percentiles relative to each sample's UV distribution. As a consequence, classes are of approximately equal size of around one-quarter of the samples' observations. As robustness check in Appendix S1, we also propose a methodology where classes are defined as the share of world's quality segments: hence, a trade flow is classified as 'low quality' if it belongs to the world's downmarket segment $\left(0-25\right.$ th). Our conclusions will be robust to such a change. ${ }^{2122}$

Equation (6) is estimated over the three samples Whole, OECD and EME - which differ according to the GDP per capita of immigrants' countries of origin - and then separately for all quality subgroups with country, time and product FE. Given the dimensionality of the data, the standard OLS estimation does not allow for the explicit inclusion of the whole set of dummy variables. With the presence of two high-dimensional fixed effects, the alternative strategy includes

\footnotetext{
${ }^{19}$ We perform the same analysis with $K=10$, that is by dividing the spectrum of traded goods based on relative unit values into deciles: the lowest quality segment lies under the 10th percentile, whereas the upmarket segment above the 90th percentile, in between the other intermediate classes. The statistics and the discussion of the results are presented in Appendix S1.

${ }^{20}$ Using World's UV quartiles as benchmark to define quality classes would implicitly impose in each segment, the same degree of heterogeneity in terms of efficiencies across countries. The motivations in support of this choice as well as the robustness checks with the alternative classification are outlined in Appendix S1

${ }^{21}$ Further details on the two methodologies are outlined in Appendix S1.

22 The consistency of our results is supported by numerous robustness checks whose results and methodologies are discussed and reported in Appendix S1.
} 
the application of an iterative approach incorporating two high-dimensional fixed effects (2WFE hereafter), namely Si and Sg in our case. The 2WFE approach, developed by Guimaraes and Portugal (2010), is based on the full Gauss-Seidel algorithm and allows for estimating linear regressions model with two high-dimensional fixed effects under minimal memory requirements. Head and Mayer (2014) find that 2WFE estimator yields identical estimates to the least squares with country dummies (LSDV) while not being subject to arbitrary limits. ${ }^{23}$

Given the presence of zero observations in the migration database, and following the suggestion of Dunlevy (2006) among others, we set $\ln \left(\mathrm{mig}_{n i}+1\right)$ to avoid the loss of more than 30,000 of information. ${ }^{24}$ Finally, a major econometric issue which arises when estimating this gravity equation is the endogeneity bias that may derive from measurement errors, omitted variables or potential reverse causality between the dependent variable, imports from country $i$ to country $n$ and the variable of interest, the stock of immigrants from country $i$ and resident in country $n$. As a robustness check, we follow Combes et al. (2005), Briant et al. (2014) by instrumenting the stocks of immigrants with past bilateral stocks. Given the irrelevancy of other instruments that emerge in our first-step analysis, as IV we select the time varying 15 years lag in our exactly identified 2SLS model since these are the earliest stocks of bilateral high-skilled immigrants available from Brucker et al. (2013). ${ }^{25}$ Due to the presence of zeroes also in the

\footnotetext{
${ }^{23}$ There are alternative methodologies that can be used to tackle the issue of heteroscedasticity (and to avoid the bias derived from the presence of the zeros in the dependent variable which is not an issue in our case), see Briant et al. (2014) for a discussion. Unfortunately, PPML estimation with several highdimensional fixed effects in estimating equation (6) led to non-convergence. Our workaround strategy consists on estimating the same model by including a reduced number of three-digit industry FE, a similar strategy implemented by Chen and Novy (2011). Following Head and Mayer (2014) we perform a robustness check with Poisson PML and gamma PML with three-digit industry FE: we find similar results across all estimators. We briefly discuss the results and the methodologies in Appendix S1.

${ }^{24}$ To be precise, the use of $\ln \left(m i g_{n i}+1\right)$ as a covariate of $X_{n i, g, t}^{k}$ in the estimation of equation (6) instead of $\ln \left(\mathrm{mig}_{n i}\right)$ to avoid the zeroes problem implies that the reported coefficients are not elasticities but semi-elasticities. In fact, the elasticity denoted by $\in$ is: $(\theta \ln X / \theta \operatorname{lnm} i g)=(\theta \ln (X) /$ $\theta \ln (m i g))(\theta \ln (m i g) / \theta \ln (1+m i g))=\theta(X / 1+m i g)$, where $\theta$ is the reported estimate, so that if $m i g=0$, then $\in=0$. In line with thevery recent literature (see for instance Bratti et al. 2014), we will not make this distinction, and for simplicity in the following discussion, we refer to the elasticity of immigrants as the pro-trade effect of one plus the stock of bilateral immigrants.

${ }^{25}$ Along with the lagged stocks of migrants Ehrhart et al. (2014) utilise - (i) the difference in life expectancy between importer and exporter and (ii) a dummy which equals one if a bilateral social security agreement exists between the two countries - as additional instruments in a similar gravity framework. We do not include the difference in life expectancy as additional IV for three main reasons. First, this instrument is likely to be ineffective for the OECD sample, in which the differences in life expectancy are quite small and they are unlikely to be correlated with the stocks of immigrants. Second, we show in Appendix S2 for the EME sample - where difference in life expectancy is certainly larger and they may have a more prominent effect on the size of migrants community - that the instrument is uncorrelated with the endogenous variable. Third, this instrument is available for the whole stock and not separately for the high skill. Further details are included in Appendix S2. As for the dummy which equals one if a bilateral social security agreement exists between the two countries, the vast majority of bilateral social security agreements stipulated prior to year 2000 by OECD countries included in our sample such as Canada, USA and Australia are signed with other OECD countries, mainly EU members which would undermine the adequacy of our choice of dividing samples according to income per capita of country of origin (issue of self-selection). Perhaps more importantly, the correlation of this instrument with the bilateral stock of immigrants should be analysed more carefully: for instance, the data from Brucker et al. (2013) indicate that the emigrants from Maghreb countries to OECD economies (including Portugal, Spain and France) progressively decrease since 1980, which seems to indicate a negligible role of social security agreements of EU with different Maghreb countries (Algeria, Morocco and Tunisia) through the EuroMed Partnership.
} 


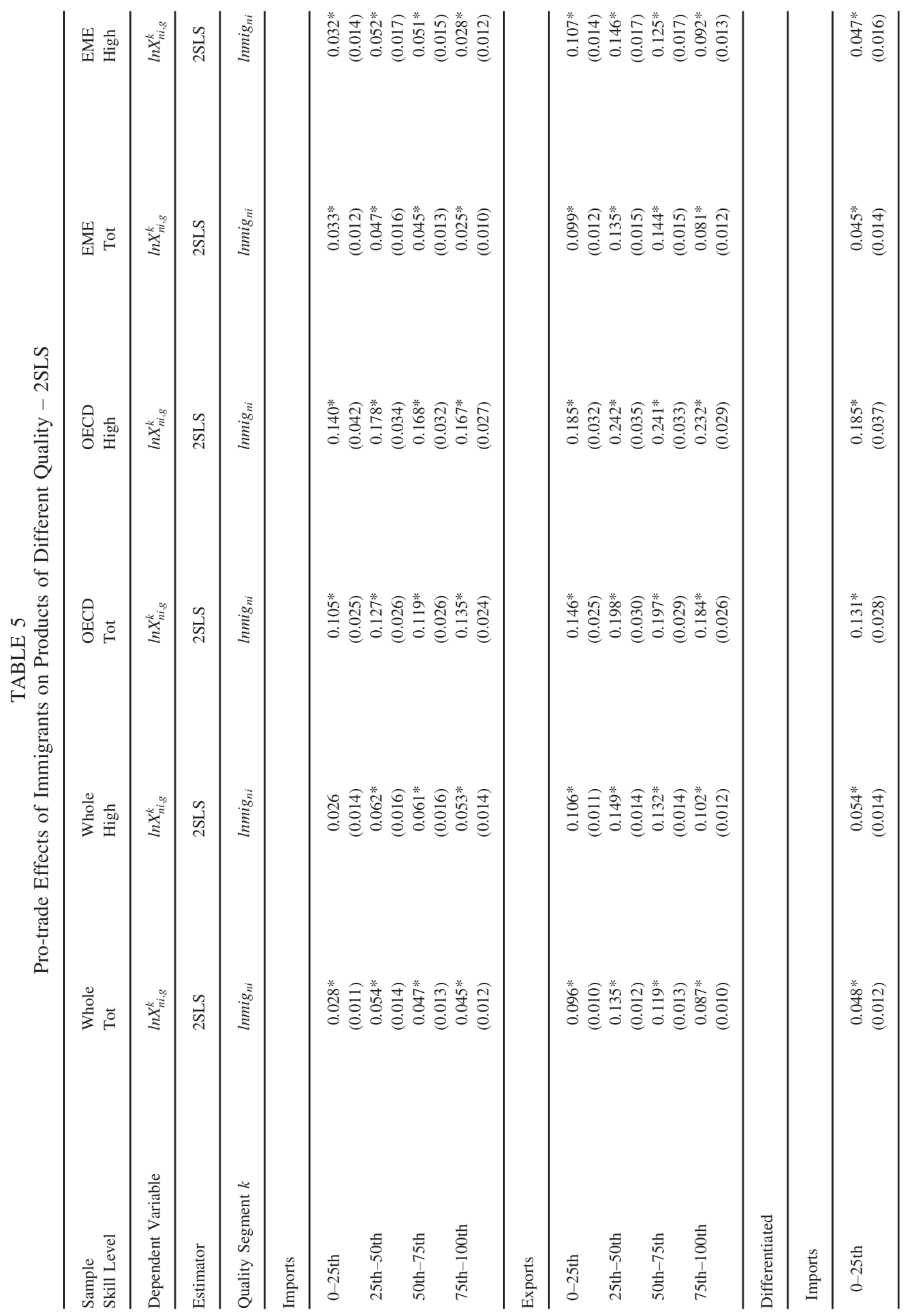




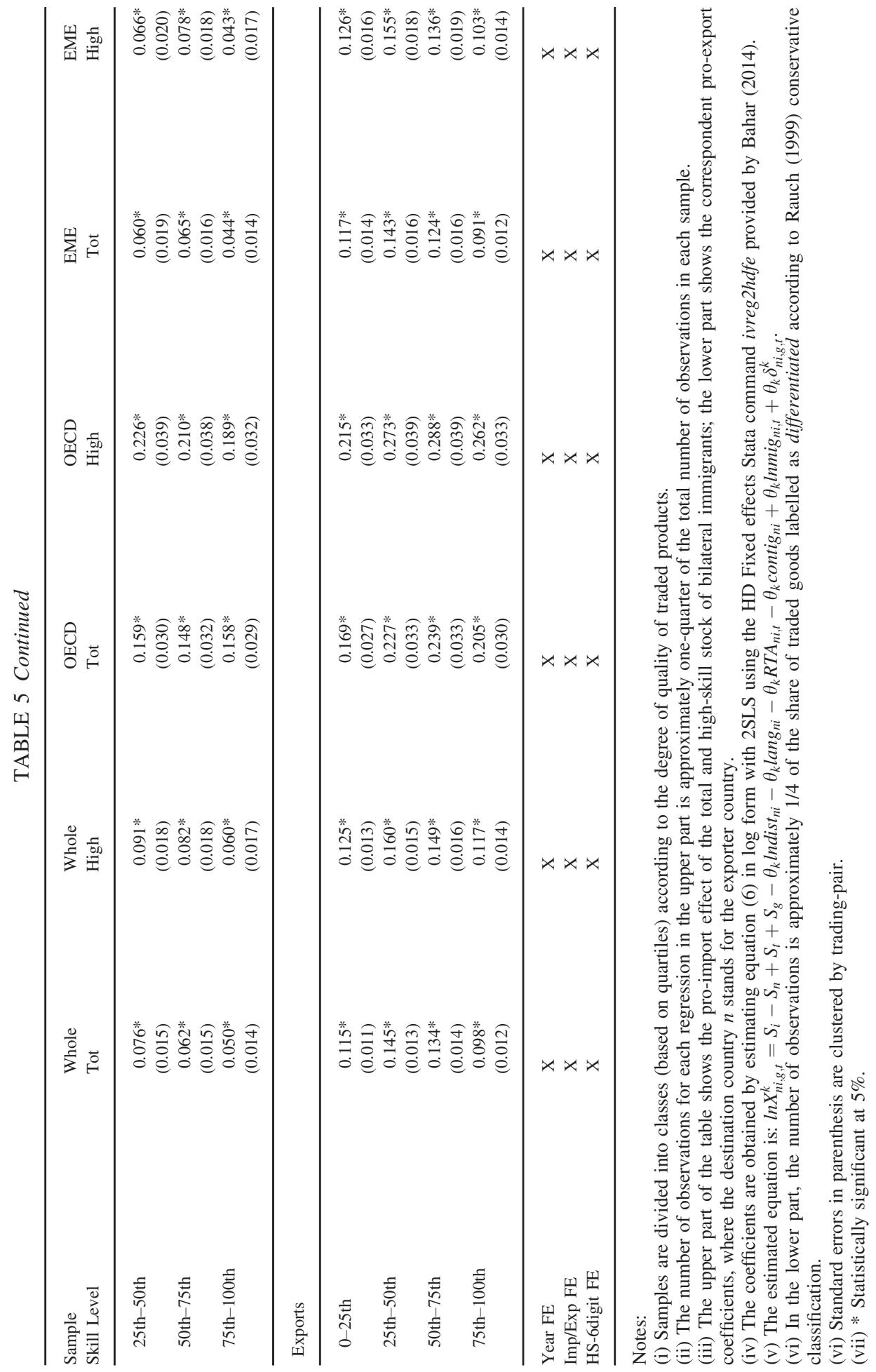




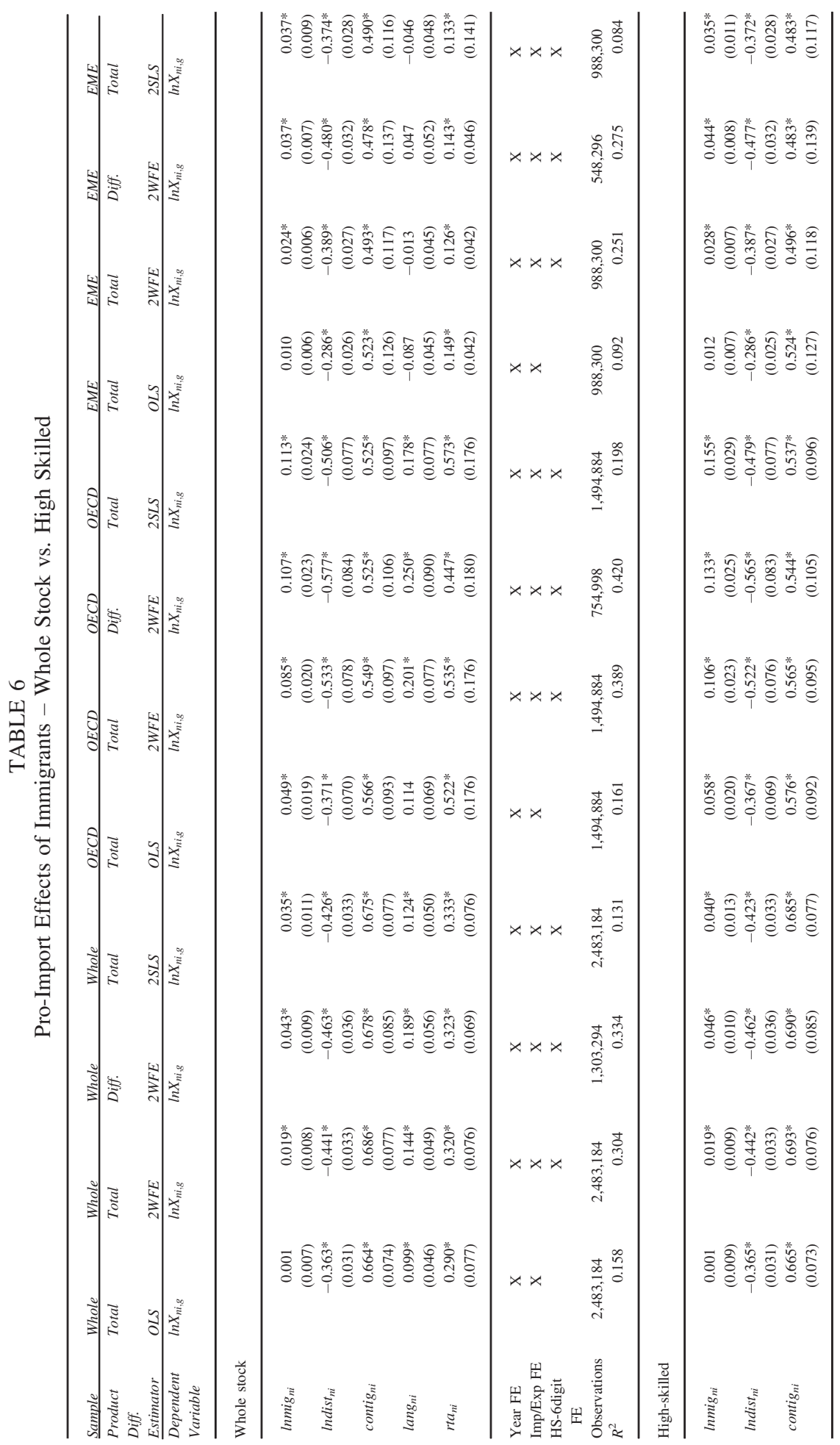




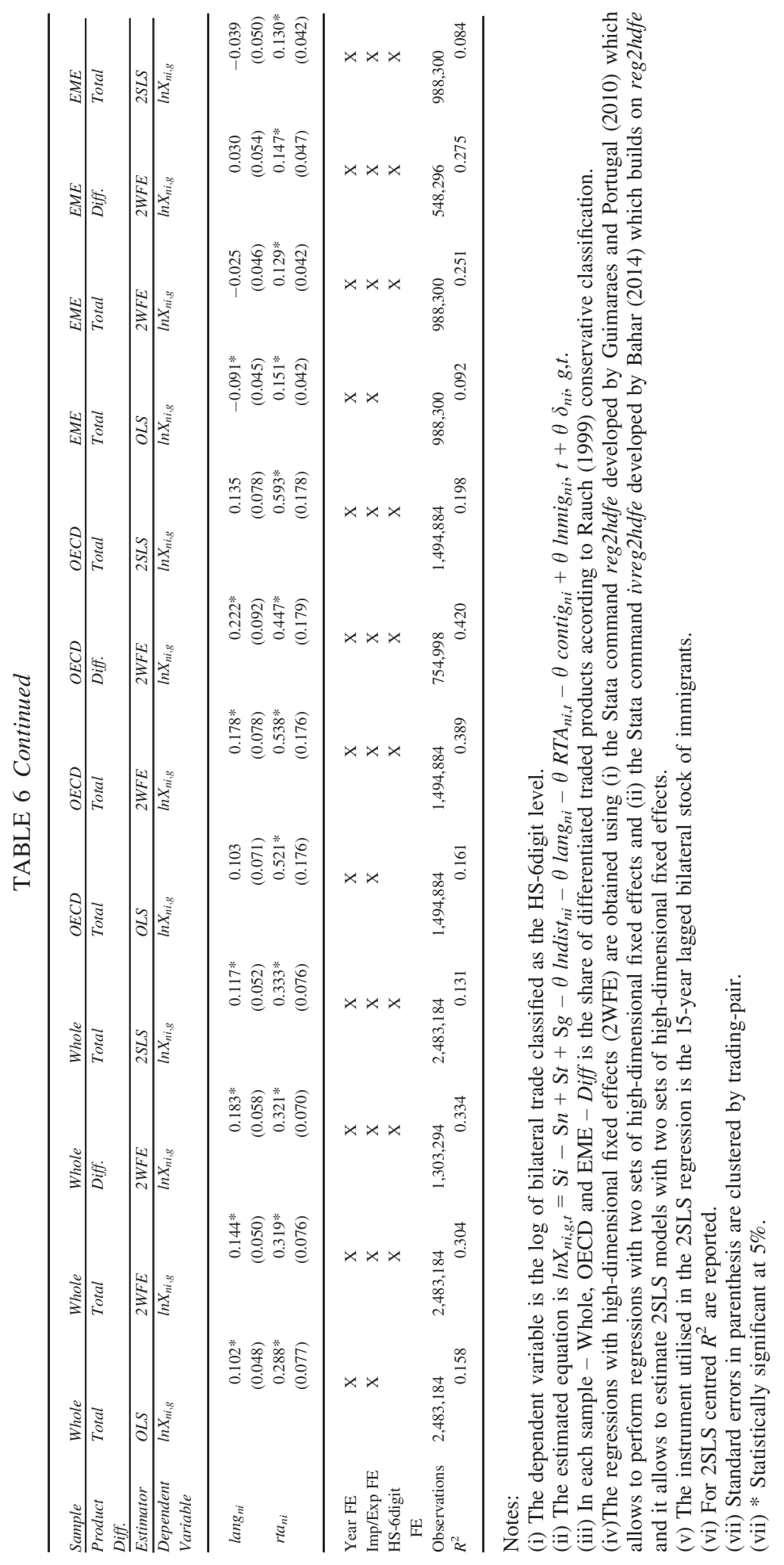




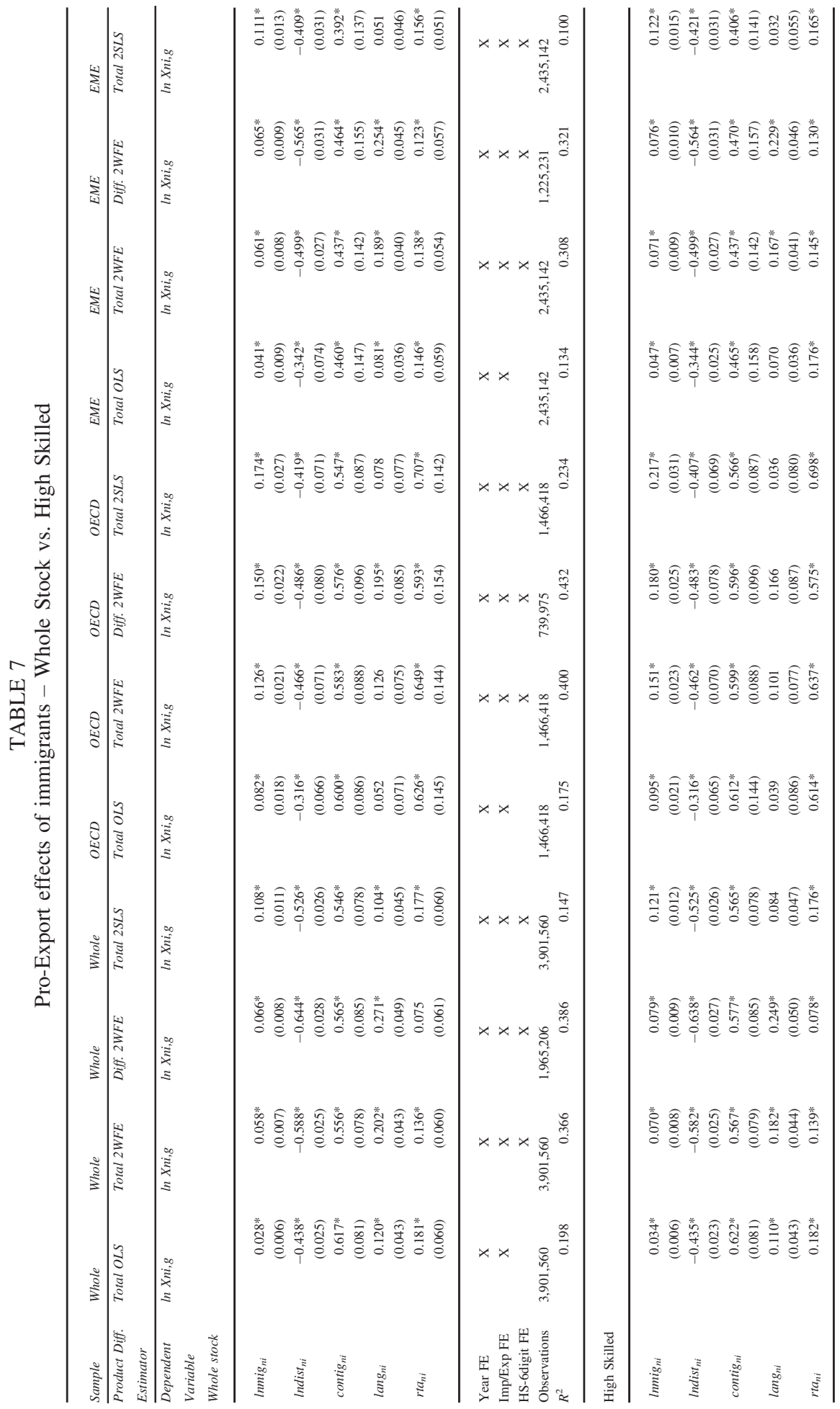




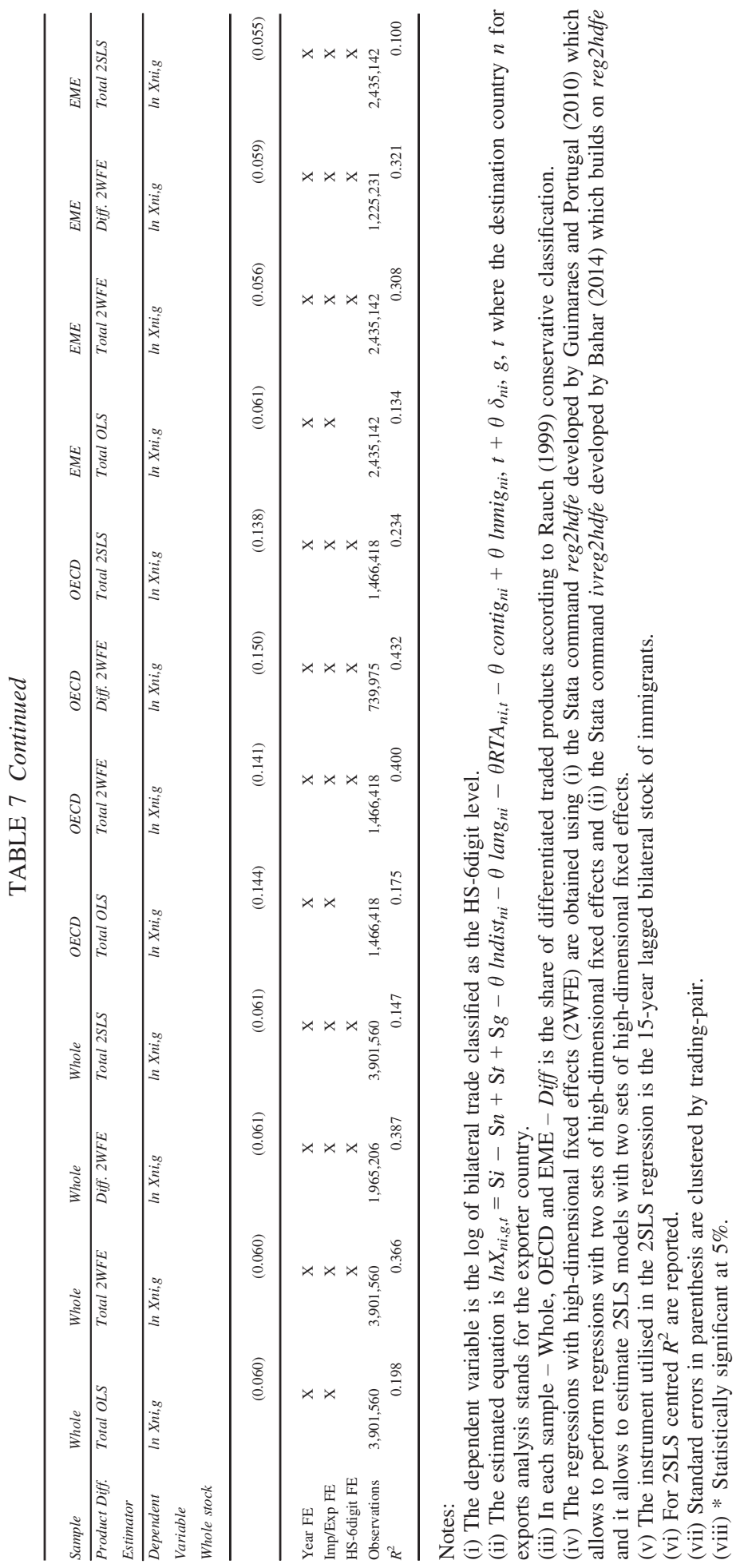


lagged bilateral stocks of migrants, to preserve the same number of observations in OLS and IV-OLS regressions we set $\ln \left(\mathrm{mig}_{n i}+1\right)$ also for lagged stocks. In order to perform the instrumental variable regressions with two sets of HD fixed effects and to check for the instruments validity, we utilise the STATA command ivreg2hdfe recently written by Bahar (2014) which builds on reg2hdfe. The 2SLS results as well as the tests for the validity of instruments are reported and discussed in Table 5 and in Appendices S1 and S2. ${ }^{26}$

\section{RESULTS}

Table 6 reports the OLS estimates of equation (6) with log of imports as dependent variable for the three different samples, that is OECD countries, emerging and developing economies and the complete sample, separately for all the migrants and for the high skill. Table 7 shows the correspondent estimates for exports. In these preliminary estimates, we aim at replicating some of the stylised facts that emerge from the literature. The evidence clearly shows that the exclusion of HS-6 digit product FE makes the model underspecified and the relevant omitted explanatory variables cause the coefficients to be biased downward. When estimating the model with 2WFE the $R^{2}$ almost doubles and all the effects are larger in absolute value: in the whole sample the pro-import effect of immigrants becomes positive and statistically significant only when we include HS-6 digit industry FE, where a 10 per cent increase in immigrant stocks leads to a 0.19 per cent increase in import flows. ${ }^{27}$ The coefficients of dist $_{n i}$, contig $_{n i}$ and $R T A_{n i, t}$ have all the expected sign. In general, the pro-trade coefficients are substantially lower in magnitude in comparison with the elasticities of several influential papers summarised in Bratti et al. (2014): this is particularly evident for imports' elasticities. ${ }^{28}$ Lastly, in line with the literature (see for instance Combes et al. 2005) the 2SLS protrade coefficients are always larger - even if slightly so - when instrumented.

Contrary to the traditional findings of the literature, in each sample (Whole, EME and OECD) the pro-export effects of immigrants are significantly higher than that of imports: therefore, there is no evidence of the so-called transplanted home bias, or more simply, this gap in favour of exports' elasticities is an indication of a marginal role of consumer preferences as determinant of the protrade effect of immigrants. A possible interpretation is that the promotion of bilateral trade of ethnic networks passes mainly through the trade cost channel, that is the ability of immigrants in reducing transaction costs and overcoming informal trade barriers. ${ }^{29}$

The results shown in Tables 6 and 7 seem to contrast those of Bratti et al. (2014) and Ehrhart et al. (2014) who find larger pro-trade effects of immigrants from low-income economies. Ehrhart et al. (2014) argue that the large pro-export effect of African migrants could be partly

\footnotetext{
${ }^{26}$ On top of the IV approach, we tackle the issue of measurement error by following Hallak (2006) who exclude potential outliers from their database. The details on the procedure we implement and the results are outlined in Appendix S1.

${ }^{27}$ In Appendix S1 we perform some robustness checks with OLS by including three-digit industry dummies instead of six-digit industry FE: the pro-import coefficients remain all statistically not significant.

28 Briant et al. (2014) found an elasticity of imports with respect to the stock of immigrants of 0.12 , Girma and Yu (2002) obtained 0.10, whereas Head and Ries (1998), Dunlevy and Hutchinson (1999) and Wagner et al. (2002) obtained elasticities higher than 0.20.

${ }_{29}$ This finding is in line with Gould (1994) and Girma and Yu (2002) who find larger pro-trade effect of immigrants for exports. Moreover, the more recent paper of Aleksynska and Peri (2014) - which utilises the same BACI database for trade data - find some evidence of higher pro-export effects when dividing traded products according to their level of elasticity of substitution.
} 
TABLE 8

Pro-trade Effects of Immigrants on Products of Different Quality

\begin{tabular}{|c|c|c|c|c|c|c|}
\hline Sample & Whole & Whole & OECD & OECD & EME & EME \\
\hline Skill Level & Tot & High & Tot & High & Tot & High \\
\hline Dependent Variable & $\ln X_{n i, g}^{k}$ & $\ln X_{n i, g}^{k}$ & $\ln X_{n i, g}^{k}$ & $\ln X_{n i, g}^{k}$ & $\ln X_{n i, g}^{k}$ & $\ln X_{n i, g}^{k}$ \\
\hline Estimator & 2WFE & 2WFE & 2WFE & 2WFE & 2WFE & 2WFE \\
\hline Quality Segment $k$ & $\operatorname{lnmig}_{n i}$ & $\operatorname{lnmig}_{n i}$ & $\operatorname{lnmig}_{n i}$ & $\operatorname{lnmig}_{n i}$ & $\operatorname{lnmig}_{n i}$ & $\operatorname{lnmig}_{n i}$ \\
\hline \multicolumn{7}{|l|}{ Imports } \\
\hline $0-25$ th & $\begin{array}{c}0.020 * \\
(0.008)\end{array}$ & $\begin{array}{c}0.019 * \\
(0.009)\end{array}$ & $\begin{array}{c}0.072 * \\
(0.020)\end{array}$ & $\begin{array}{c}0.079^{*} \\
(0.021)\end{array}$ & $\begin{array}{c}0.029 * \\
(0.007)\end{array}$ & $\begin{array}{c}0.033^{*} \\
(0.009)\end{array}$ \\
\hline 25 th -50 th & $\begin{array}{c}0.031^{*} \\
(0.009)\end{array}$ & $\begin{array}{c}0.030^{*} \\
(0.010)\end{array}$ & $\begin{array}{c}0.093 * \\
(0.023)\end{array}$ & $\begin{array}{c}0.106^{*} \\
(0.026)\end{array}$ & $\begin{array}{c}0.039 * \\
(0.008)\end{array}$ & $\begin{array}{r}0.047^{*} \\
(0.009)\end{array}$ \\
\hline 50th-75th & $\begin{array}{c}0.031 * \\
(0.010)\end{array}$ & $\begin{array}{c}0.035^{*} \\
(0.012)\end{array}$ & $\begin{array}{c}0.098^{*} \\
(0.023)\end{array}$ & $\begin{array}{c}0.124 * \\
(0.025)\end{array}$ & $\begin{array}{c}0.028^{*} \\
(0.007)\end{array}$ & $\begin{array}{r}0.036^{*} \\
(0.008)\end{array}$ \\
\hline 75th-100th & $\begin{array}{c}0.027 * \\
(0.009)\end{array}$ & $\begin{array}{c}0.032 * \\
(0.011)\end{array}$ & $\begin{array}{c}0.112 * \\
(0.019)\end{array}$ & $\begin{array}{c}0.140^{*} \\
(0.021)\end{array}$ & $\begin{array}{c}0.013 \\
(0.007)\end{array}$ & $\begin{array}{c}0.014 \\
(0.008)\end{array}$ \\
\hline \multicolumn{7}{|l|}{ Exports } \\
\hline $0-25$ th & $\begin{array}{c}0.051^{*} \\
(0.006)\end{array}$ & $\begin{array}{c}0.059 * \\
(0.007)\end{array}$ & $\begin{array}{c}0.098^{*} \\
(0.020)\end{array}$ & $\begin{array}{c}0.115^{*} \\
(0.023)\end{array}$ & $\begin{array}{c}0.056^{*} \\
(0.007)\end{array}$ & $\begin{array}{c}0.063^{*} \\
(0.008)\end{array}$ \\
\hline 25 th -50 th & $\begin{array}{c}0.073^{*} \\
(0.007)\end{array}$ & $\begin{array}{c}0.083^{*} \\
(0.008)\end{array}$ & $\begin{array}{c}0.145^{*} \\
(0.023)\end{array}$ & $\begin{array}{c}0.164 * \\
(0.026)\end{array}$ & $\begin{array}{c}0.071 * \\
(0.008)\end{array}$ & $\begin{array}{c}0.080 * \\
(0.009)\end{array}$ \\
\hline 50th-75th & $\begin{array}{c}0.064 * \\
(0.008)\end{array}$ & $\begin{array}{c}0.078^{*} \\
(0.009)\end{array}$ & $\begin{array}{c}0.146^{*} \\
(0.022)\end{array}$ & $\begin{array}{c}0.171^{*} \\
(0.025)\end{array}$ & $\begin{array}{c}0.061 * \\
(0.009)\end{array}$ & $\begin{array}{c}0.072 * \\
(0.010)\end{array}$ \\
\hline 75th-100th & $\begin{array}{c}0.057 * \\
(0.007)\end{array}$ & $\begin{array}{c}0.073 * \\
(0.009)\end{array}$ & $\begin{array}{c}0.140^{*} \\
(0.020)\end{array}$ & $\begin{array}{c}0.178^{*} \\
(0.022)\end{array}$ & $\begin{array}{c}0.051^{*} \\
(0.008)\end{array}$ & $\begin{array}{r}0.063^{*} \\
(0.009)\end{array}$ \\
\hline \multicolumn{7}{|l|}{$\begin{array}{l}\text { Differentiated } \\
\text { Imports }\end{array}$} \\
\hline $0-25$ th & $\begin{array}{c}0.038^{*} \\
(0.008)\end{array}$ & $\begin{array}{c}0.040^{*} \\
(0.010)\end{array}$ & $\begin{array}{c}0.094 * \\
(0.022)\end{array}$ & $\begin{array}{c}0.107 * \\
(0.024)\end{array}$ & $\begin{array}{c}0.036^{*} \\
(0.008)\end{array}$ & $\begin{array}{c}0.040 * \\
(0.010)\end{array}$ \\
\hline 25 th-50th & $\begin{array}{c}0.056^{*} \\
(0.010)\end{array}$ & $\begin{array}{c}0.059 * \\
(0.011)\end{array}$ & $\begin{array}{c}0.121^{*} \\
(0.025)\end{array}$ & $\begin{array}{c}0.139 * \\
(0.028)\end{array}$ & $\begin{array}{c}0.052 * \\
(0.009)\end{array}$ & $\begin{array}{r}0.063^{*} \\
(0.010)\end{array}$ \\
\hline 50th-75th & $\begin{array}{c}0.052^{*} \\
(0.011)\end{array}$ & $\begin{array}{c}0.060^{*} \\
(0.013)\end{array}$ & $\begin{array}{c}0.116^{*} \\
(0.026)\end{array}$ & $\begin{array}{c}0.148^{*} \\
(0.029)\end{array}$ & $\begin{array}{c}0.038^{*} \\
(0.009)\end{array}$ & $\begin{array}{r}0.048^{*} \\
(0.010)\end{array}$ \\
\hline 75th-100th & $\begin{array}{c}0.034 * \\
(0.011)\end{array}$ & $\begin{array}{c}0.040 * \\
(0.013)\end{array}$ & $\begin{array}{c}0.122^{*} \\
(0.022)\end{array}$ & $\begin{array}{c}0.148^{*} \\
(0.024)\end{array}$ & $\begin{array}{c}0.024 * \\
(0.009)\end{array}$ & $\begin{array}{c}0.026^{*} \\
(0.011)\end{array}$ \\
\hline \multicolumn{7}{|l|}{ Exports } \\
\hline $0-25$ th & $\begin{array}{c}0.062 * \\
(0.007)\end{array}$ & $\begin{array}{c}0.071 * \\
(0.008)\end{array}$ & $\begin{array}{c}0.119^{*} \\
(0.021)\end{array}$ & $\begin{array}{c}0.139^{*} \\
(0.024)\end{array}$ & $\begin{array}{c}0.065^{*} \\
(0.008)\end{array}$ & $\begin{array}{c}0.073^{*} \\
(0.009)\end{array}$ \\
\hline 25 th-50th & $\begin{array}{c}0.081^{*} \\
(0.008)\end{array}$ & $\begin{array}{c}0.091 * \\
(0.010)\end{array}$ & $\begin{array}{c}0.171^{*} \\
(0.023)\end{array}$ & $\begin{array}{c}0.191 * \\
(0.028)\end{array}$ & $\begin{array}{c}0.074 * \\
(0.009)\end{array}$ & $\begin{array}{c}0.084^{*} \\
(0.010)\end{array}$ \\
\hline 50 th- 75 th & $\begin{array}{c}0.070 * \\
(0.009)\end{array}$ & $\begin{array}{c}0.084 * \\
(0.011)\end{array}$ & $\begin{array}{c}0.172 * \\
(0.023)\end{array}$ & $\begin{array}{c}0.196^{*} \\
(0.028)\end{array}$ & $\begin{array}{c}0.064 * \\
(0.010)\end{array}$ & $\begin{array}{r}0.077^{*} \\
(0.011)\end{array}$ \\
\hline 75th-100th & $\begin{array}{c}0.056^{*} \\
(0.008)\end{array}$ & $\begin{array}{c}0.074 * \\
(0.010)\end{array}$ & $\begin{array}{c}0.150^{*} \\
(0.022)\end{array}$ & $\begin{array}{c}0.193^{*} \\
(0.025)\end{array}$ & $\begin{array}{c}0.052^{*} \\
(0.009)\end{array}$ & $\begin{array}{c}0.065^{*} \\
(0.010)\end{array}$ \\
\hline
\end{tabular}


TABLE 8 Continued

\begin{tabular}{lllllll}
\hline $\begin{array}{l}\text { Sample } \\
\text { Skill Level }\end{array}$ & Whole & Whole & OECD & OECD & EME \\
Tot & High & Tot & Tot & $\begin{array}{l}\text { EME } \\
\text { High }\end{array}$ \\
\hline Year FE & $\mathrm{X}$ & $\mathrm{X}$ & $\mathrm{X}$ & $\mathrm{X}$ & $\mathrm{X}$ & $\mathrm{X}$ \\
Imp/Exp FE & $\mathrm{X}$ & $\mathrm{X}$ & $\mathrm{X}$ & $\mathrm{X}$ & $\mathrm{X}$ & $\mathrm{X}$ \\
HS-6digit FE & $\mathrm{X}$ & $\mathrm{X}$ & $\mathrm{X}$ & $\mathrm{X}$ & $\mathrm{X}$ & $\mathrm{X}$ \\
\hline
\end{tabular}

Notes:

(i) Samples are divided into classes (based on quartiles) according to the degree of quality of traded products.

(ii) The number of observations for each quality segment in the upper part is approximately one-quarterof the total number of observations.

(iii) The upper part of the table shows the pro-import effect of the total and high-skill stock of bilateral immigrants; the lower part shows the correspondent pro-export coefficients, where the destination country $n$ stands for the exporter country.

(iv) The coefficients are obtained by estimating equation (6) in log form with 2WFE using the HD Fixed effects Stata command reg2hdfe provided by Guimaraes and Portugal (2010).

(v) The estimated equation is: ${\ln X_{n i, g, t}^{k}}_{2}=S_{i}-S_{n}+S_{t}+S_{g}-\theta_{k}$ lndist $_{n i}-\theta_{k}$ lang $_{n i}-\theta_{k}$ RTA $_{n i, t}-\theta_{k}$ contig $_{n i}$ $+\theta_{k} \operatorname{lnmig}_{n i, t}+\theta_{k} \delta_{n i, g, t}^{k}$ Detailed information on number of observations, $R^{2}$ and first-stage coefficients for each regression is available upon request.

(vi) In the lower part, Differentiated refers to the reduced sample composed by the share of differentiated traded products according to Rauch (1999) conservative classification; in the lower part for each quality segment the number of observations is approximately one-quarter of the share of traded goods labelled as differentiated.

(vii) Standard errors in parenthesis are clustered by trading-pair.

(viii) * Statistically significant at $5 \%$.

explained by the existence of weaker institutions in Africa for which migrants' networks provide a substitute. In Ehrhart et al. (2014) the effect appears also particularly important for exports of differentiated products, suggesting that migrants also play an important role in reducing information costs. This interpretation can harmlessly be extended to all emerging economies of our sample. Our estimates suggest that as the sample expands by including less developed countries, the elasticities of immigrants decrease significantly.

The upper part of Table 8 reports the elasticity of trade flows with respect to the stocks of immigrants for all quality segments. Regardless of the quality of commodities, pro-export coefficients are larger in magnitude than those of imports. Furthermore, the pro-trade elasticity of immigrants exhibits a very similar trend over quality both for imports and exports. However, these trends significantly vary by sample: the pro-trade effect of ethnic networks from low-income economies is relatively lower for varieties of high quality, whereas immigrants from OECD exhibit the lowest effects for low-quality products.

Our interpretation of these results hinges on the empirical regularities that emerge from the literature regarding the market positioning of traded products and the specialisation across varieties between North and South. More precisely, on the one hand the trend of the proimport effect of immigrants over quality seems to reflect the comparative advantage of their country of origin: since advanced economies are keeping an advantage in the upper market segment, the pro-import action of their ethnic networks - through their role in the matching of trading opportunities - will be stronger for upper market varieties. Our hypothesis is that immigrants have more information advantages in the quality segment where their country of origin is specialised. Table 8 shows that for the OECD sample the pro-import elasticity of immigrants augment with the quality of traded products: as we move up in the quality ladder the coefficient steadily increases. For the same argument, as we expand the sample by including emerging economies the highest impact is on the low-medium segment (25th-50th) since the South keeps an edge over relatively cheap varieties. 
On the other hand, ethnic networks seem to promote exports to their homeland of products for which there is relatively higher demand. Developing countries spend a relatively higher share of their income on low-quality products and import products of lower quality. Therefore, immigrants from developing countries residing in Europe will tend to facilitate export opportunities to their homeland - through provision of market information or helping producers to find appropriate distributors - for varieties of low quality compared to the top-quality segment.

Although the trend of elasticities which emerges from Table 8 may be related to the different shares of highly differentiated products across quality classes, we show empirically that the same trend applies to the category of products labelled as differentiated in Rauch (1999) classification. We first consider a reduced sample with only the share of products labelled as differentiated and we perform the same classification in quartiles previously described. The results are reported in the lower part of Table 8. The trend remains substantially unchanged: even though we are estimating the effect of immigrants on traded goods with the exactly same degree of differentiation, the variation of the impact of ethnic networks is still determined by the quality of products traded. We infer that (i) the degree of differentiation according to Rauch (1999) classification is not a substitute for quality, and (ii) along with the signals of reference price and whether or not the good is traded on organised exchange the quality of traded products is an important determinant of the pro-trade effects of immigrants.

As it emerges from the estimates, the elasticities of skilled ethnic networks appear to be larger than the total stock. ${ }^{30}$ Given their lower liquidity constraints and advantages in human capital, high-skilled immigrants exert a stronger pro-trade effect. Notably, the results suggest that the relationship between product quality and pro-trade elasticity of ethnic networks does not depend on the composition of the stock of immigrants by skill level: the trend over quality remains unaffected, meaning that our interpretation related to the link between ethnic networks effect and North-South specialisation across varieties applies for the high-skill as well.

As robustness check, we have replicated the same empirical exercise using the TUV data set developed by CEPII. Since in the TUV data set the whole list of importers and exporters is available only from 2002, we estimate a cross-section model where the networks' effect in the year 2000 is estimated on the $\log$ of trade at $t+2$. This does not cause any concern related to the quality of our estimates: on the contrary, estimating a model where the stock of immigrants is further predetermined with respect to trade is identified in the literature as an additional strategy to alleviate the issue of potential joint determination of migration and trade (see for instance Aleksynska and Peri 2014). ${ }^{31}$ The estimates are reported in Table 9. The results are in line with our expectations and with the previous ones. Also the 2SLS estimates in Table 5 essentially confirm our main findings. In particular, the lowest pro-trade effects of ethnic networks from OECD countries are for the lowest 0th-25th quality segment - the segment for which developed countries exhibit relatively lower demand and have a comparative disadvantage in the supply side. The same reasoning applies to the pro-trade effects of immigrants from developing countries. By augmenting the gravity equation with $S_{i g t}$ and $S_{n g t}$ the fit of the estimated model significantly increases. As shown in the upper part of Table 3 , the estimates of the augmented model in general provide larger network effects which are much closer in magnitude to the recent literature (see Genc et al. 2012, Bratti et al. 2014).

\footnotetext{
30 The only exceptions are the first two quality segments of the whole sample, where the pro-import coefficient of the high skill shows a slightly lower effect.

31 Aleksynska and Peri (2014) use the $\log$ of trade at $t+2$ and $t+5$ as a dependent variable. Further information on the issues related to data availability in TUV data set is presented in the Appendix.
} 
TABLE 9

Pro-trade Effects of Immigrants on Products of Different Quality - TUV Data Set

\begin{tabular}{|c|c|c|c|c|c|c|}
\hline $\begin{array}{l}\text { Sample } \\
\text { Skill Level }\end{array}$ & $\begin{array}{l}\text { Whole } \\
\text { Tot }\end{array}$ & $\begin{array}{l}\text { Whole } \\
\text { High }\end{array}$ & $\begin{array}{l}\text { OECD } \\
\text { Tot }\end{array}$ & $\begin{array}{l}\text { OECD } \\
\text { High }\end{array}$ & $\begin{array}{l}\text { EME } \\
\text { Tot }\end{array}$ & $\begin{array}{l}\text { EME } \\
\text { High }\end{array}$ \\
\hline Dependent Variable & $\begin{array}{l}\ln X_{n i, g}^{k} k \\
t+2\end{array}$ & $\begin{array}{l}\ln X_{n i, g}^{k} k \\
t+2\end{array}$ & $\begin{array}{l}\ln X_{n i, g}^{k} \\
t+2\end{array}$ & $\begin{array}{l}\ln X_{n i, g}^{k} \\
t+2\end{array}$ & $\begin{array}{l}\ln X_{n i, g}^{k} \\
t+2\end{array}$ & $\begin{array}{l}\ln X_{n i, g}^{k} \\
t+2\end{array}$ \\
\hline Estimator & 2WFE & 2WFE & $2 \mathrm{WFE}$ & 2WFE & 2WFE & $2 \mathrm{WFE}$ \\
\hline Quality Segment $k$ & $\operatorname{lnmig}_{n i}$ & $\operatorname{lnmig}_{n i}$ & $\operatorname{lnmig}_{n i}$ & $\operatorname{lnmig}_{n i}$ & $\operatorname{lnmig}_{\mathrm{ni}}$ & $\operatorname{lnmig}_{\mathrm{ni}}$ \\
\hline \multicolumn{7}{|l|}{ Imports } \\
\hline $0-25$ th & $\begin{array}{c}0.035^{*} \\
(0.007)\end{array}$ & $\begin{array}{c}0.046^{*} \\
(0.009)\end{array}$ & $\begin{array}{c}0.096^{*} \\
(0.022)\end{array}$ & $\begin{array}{c}0.146^{*} \\
(0.027)\end{array}$ & $\begin{array}{c}0.032 * \\
(0.008)\end{array}$ & $\begin{array}{c}0.046^{*} \\
(0.010)\end{array}$ \\
\hline 25 th-50th & $\begin{array}{c}0.047^{*} \\
(0.009)\end{array}$ & $\begin{array}{c}0.060 * \\
(0.011)\end{array}$ & $\begin{array}{l}0.118^{*} \\
(0.025)\end{array}$ & $\begin{array}{l}0.179^{*} \\
(0.029)\end{array}$ & $\begin{array}{c}0.033^{*} \\
(0.007)\end{array}$ & $\begin{array}{c}0.047^{*} \\
(0.009)\end{array}$ \\
\hline 50th-75th & $\begin{array}{c}0.041 * \\
(0.010)\end{array}$ & $\begin{array}{c}0.055^{*} \\
(0.012)\end{array}$ & $\begin{array}{l}0.118^{*} \\
(0.024)\end{array}$ & $\begin{array}{l}0.177 * \\
(0.029)\end{array}$ & $\begin{array}{c}0.024 * \\
(0.007)\end{array}$ & $\begin{array}{r}0.033^{*} \\
(0.009)\end{array}$ \\
\hline 75th-100th & $\begin{array}{c}0.031 * \\
(0.009)\end{array}$ & $\begin{array}{c}0.036^{*} \\
(0.011)\end{array}$ & $\begin{array}{c}0.116^{*} \\
(0.021)\end{array}$ & $\begin{array}{c}0.151 * \\
(0.025)\end{array}$ & $\begin{array}{c}0.016^{*} \\
(0.007)\end{array}$ & $\begin{array}{r}0.020^{*} \\
(0.008)\end{array}$ \\
\hline \multicolumn{7}{|l|}{ Exports } \\
\hline $0-25$ th & $\begin{array}{c}0.067 * \\
(0.008)\end{array}$ & $\begin{array}{c}0.083^{*} \\
(0.009)\end{array}$ & $\begin{array}{c}0.150^{*} \\
(0.027)\end{array}$ & $\begin{array}{c}0.187 * \\
(0.034)\end{array}$ & $\begin{array}{c}0.057^{*} \\
(0.008)\end{array}$ & $\begin{array}{c}0.072 * \\
(0.009)\end{array}$ \\
\hline 25 th -50 th & $\begin{array}{c}0.084 * \\
(0.009)\end{array}$ & $\begin{array}{c}0.106^{*} \\
(0.011)\end{array}$ & $\begin{array}{c}0.196^{*} \\
(0.029)\end{array}$ & $\begin{array}{c}0.253^{*} \\
(0.036)\end{array}$ & $\begin{array}{c}0.064 * \\
(0.009)\end{array}$ & $\begin{array}{c}0.085^{*} \\
(0.011)\end{array}$ \\
\hline 50 th-75th & $\begin{array}{c}0.073 * \\
(0.009)\end{array}$ & $\begin{array}{c}0.095^{*} \\
(0.011)\end{array}$ & $\begin{array}{l}0.184^{*} \\
(0.025)\end{array}$ & $\begin{array}{l}0.236^{*} \\
(0.032)\end{array}$ & $\begin{array}{c}0.058^{*} \\
(0.009)\end{array}$ & $\begin{array}{c}0.079^{*} \\
(0.011)\end{array}$ \\
\hline 75th-100th & $\begin{array}{c}0.049 * \\
(0.008)\end{array}$ & $\begin{array}{c}0.064 * \\
(0.010)\end{array}$ & $\begin{array}{c}0.166^{*} \\
(0.021)\end{array}$ & $\begin{array}{l}0.220 * \\
(0.025)\end{array}$ & $\begin{array}{c}0.039 * \\
(0.007)\end{array}$ & $\begin{array}{c}0.052^{*} \\
(0.009)\end{array}$ \\
\hline Year FE & $\mathrm{X}$ & $\mathrm{X}$ & $\mathrm{X}$ & $\mathrm{X}$ & $\mathrm{X}$ & $\mathrm{X}$ \\
\hline Imp/Exp FE & $\mathrm{X}$ & $\mathrm{X}$ & $\mathrm{X}$ & $\mathrm{X}$ & $\mathrm{X}$ & $\mathrm{X}$ \\
\hline HS-6digit FE & $\mathrm{X}$ & $\mathrm{X}$ & $\mathrm{X}$ & $\mathrm{X}$ & $\mathrm{X}$ & $\mathrm{X}$ \\
\hline
\end{tabular}

Notes:

(i) Samples are divided into quartiles according to the degree of quality of traded products.

(ii) The number of observations for each quality is approximately one-quarter of the total number of observations.

(iii) Trade and Unit Values data are from the CEPII TUV data set.

(iv) The Cost of Insurance and Freight (CIF) import unit values rely on importers' declarations and include all trade costs (except tariffs and domestic taxes after the border).

(v) The Free on Board (FOB) export unit values are a proxy for the trade prices at the factory gate, relying on exporters' declarations.

(vi) They do not include trade costs.

(vii) Further details on BACI and TUV data set are presented in the Appendix.

(viii) The dependent variable is the $\log$ of bilateral trade at $t+2$, since the whole list of reporters is not available prior to 2002.

(ix) The upper part of the table shows the pro-import effect of the total and high-skill stock of bilateral immigrants; the lower part show the correspondent pro-export coefficients, where the destination country $n$ stands for the exporter country.

(x) The coefficients are obtained by estimating equation (6) with 2WFE using the HD Fixed Effects Stata command reg2hdfe provided by Guimaraes and Portugal (2010).

(xi) The estimated equation is: $\ln X_{n i, g}^{k}=S_{i}-S_{n}+S_{g}-\theta_{k}$ lndist $_{n i}-\theta_{k}$ lang $_{n i}-\theta_{k}$ RTA $_{n i}-\theta_{k}$ contig $_{n i}$ $+\theta_{k} \operatorname{lnmig}_{n i}+\theta_{k} \delta_{n i, g}^{k}$.

(xii) Standard errors in parenthesis are clustered by trading-pair.

(xiii) * Statistically significant at $5 \%$. 
Furthermore, the gap between pro-import and pro-export coefficients is now much smaller in magnitude with respect to Tables 6 and 7; however, the impact of exports is still larger. More importantly for our purposes, the trend of the pro-trade effect of immigrants over quality remains unchanged for both imports and exports and our main conclusions on the relationship between network effects and quality of traded products stand.

Table 4 reports all the gravity coefficients of the estimation of equation (6) augmented with $S_{i g t}$ and $S_{n g t}$ other than $\ln \left(m i g_{n i}\right)$ for all quality segments in the Whole, OECD and EME sample for both imports and exports. The vast majority of the gravity proxies for trade costs

TABLE 10

Inter-ethnic Spillover - Whole Sample

\begin{tabular}{|c|c|c|c|c|}
\hline \multirow{3}{*}{$\begin{array}{l}\text { Estimator } \\
\text { Dependent Variable }\end{array}$} & \multicolumn{2}{|l|}{$2 W F E$} & \multicolumn{2}{|l|}{$2 W F E$} \\
\hline & \multicolumn{2}{|l|}{$\underline{\ln X_{n i, g}^{k}}$} & \multicolumn{2}{|l|}{$\ln X_{n i, g}^{k}$} \\
\hline & \multicolumn{2}{|l|}{ Imports } & \multicolumn{2}{|l|}{ Exports } \\
\hline $\begin{array}{l}\text { Quality Segment } k \\
0-25 \text { th }\end{array}$ & $\begin{array}{c}\operatorname{lnmig}_{n i} \\
0.018 * \\
(0.007)\end{array}$ & $\begin{array}{r}\text { lnspil }_{\text {ni }} \\
0.012 \\
(0.010)\end{array}$ & $\begin{array}{c}\operatorname{lnmig}_{n i} \\
0.049 * \\
(0.006)\end{array}$ & $\begin{array}{r}\text { lnspil }_{n i} \\
0.027 * \\
(0.012)\end{array}$ \\
\hline 25 th- -50 th & $\begin{array}{l}0.028 * \\
(0.009)\end{array}$ & $\begin{array}{c}0.016 \\
(0.012)\end{array}$ & $\begin{array}{c}0.069 * \\
(0.007)\end{array}$ & $\begin{array}{r}0.036^{*} \\
(0.012)\end{array}$ \\
\hline 50 th -75 th & $\begin{array}{l}0.028 * \\
(0.010)\end{array}$ & $\begin{array}{c}0.022 \\
(0.014)\end{array}$ & $\begin{array}{l}0.061 * \\
(0.008)\end{array}$ & $\begin{array}{l}0.031 * \\
(0.013)\end{array}$ \\
\hline 75th-100th & $\begin{array}{l}0.026^{*} \\
(0.010)\end{array}$ & $\begin{array}{c}0.006 \\
(0.012)\end{array}$ & $\begin{array}{l}0.054^{*} \\
(0.007)\end{array}$ & $\begin{array}{c}0.019 \\
(0.011)\end{array}$ \\
\hline Year FE & $X$ & $\mathrm{X}$ & $X$ & $\mathrm{X}$ \\
\hline Imp/Exp FE & $X$ & $X$ & $X$ & $X$ \\
\hline HS-6digit FE & $\mathrm{X}$ & $\mathrm{X}$ & $\mathrm{X}$ & $X$ \\
\hline Quality Segment $k$ & lnmig $_{n i}$ & lnspil $_{n i}$ & lnmig $_{n i}$ & lnspil $_{n i}$ \\
\hline $0-25$ th & $\begin{array}{c}0.074 * \\
(0.012)\end{array}$ & $\begin{array}{r}0.045^{*} \\
(0.016)\end{array}$ & $\begin{array}{r}0.087 * \\
(0.012)\end{array}$ & $\begin{array}{r}0.053^{*} \\
(0.016)\end{array}$ \\
\hline 25 th -50 th & $\begin{array}{l}0.107 * \\
(0.014)\end{array}$ & $\begin{array}{l}0.063 * \\
(0.015)\end{array}$ & $\begin{array}{l}0.113^{*} \\
(0.014)\end{array}$ & $\begin{array}{l}0.077 * \\
(0.015)\end{array}$ \\
\hline 50 th-75th & $\begin{array}{l}0.115 * \\
(0.017)\end{array}$ & $\begin{array}{c}0.067^{*} \\
(0.016)\end{array}$ & $\begin{array}{c}0.107 * \\
(0.016)\end{array}$ & $\begin{array}{l}0.063 * \\
(0.019)\end{array}$ \\
\hline 75 th-100th & $\begin{array}{l}0.099 * \\
(0.021)\end{array}$ & $\begin{array}{c}0.026 \\
(0.026)\end{array}$ & $\begin{array}{c}0.084 * \\
(0.014)\end{array}$ & $\begin{array}{c}0.031 \\
(0.019)\end{array}$ \\
\hline Imp $\times$ HS-6 $\times$ Year FE & $X$ & $X$ & $X$ & $X$ \\
\hline Exp $\times$ HS- $6 \times$ Year FE & $\mathrm{X}$ & $\mathrm{X}$ & $\mathrm{X}$ & $\mathrm{X}$ \\
\hline
\end{tabular}

Notes:

(i) Samples are divided into classes (based on quartiles) according to the degree of quality of traded products.

(ii) The number of observations for each regression quality segment is approximately one-quarter of the total sample size.

(iii) The coefficients are obtained by estimating equation (6) in $\log$ form by including $\ln s p i l_{n \text { i }}$ as additional covariate.

(iv) The estimates are obtained with $2 \mathrm{WFE}$ using the HD Fixed effects Stata command reg2hdfe provided by Guimaraes and Portugal (2010).

(v) $\operatorname{lnmig}_{n i}$ and $\operatorname{lnspil}_{n i}$ are the pro-trade elasticity of immigrants and the inter-ethnic spillover coefficient, respectively.

(vi) Standard errors in parenthesis are clustered by trading-pair.

(vii) * Statistically significant at $5 \%$. 
have the expected sign, are statistically significant and vary with quality level: this evidence supports the assumption of $\theta$ being different across quality segments $k$. More specifically, the low market segment seems to be more sensitive to cultural proximity which is proxied by the common language dummy. Furthermore, the distance coefficients - which proxy both for (i) transport costs and (ii) the lack of information on products - are relatively larger in absolute value for low-quality segments. This is in line with our theoretical predictions and the findings of Fontagné et al. (2008). ${ }^{32}$

Lastly, Table 10 reports the pro-trade elasticities of immigrants when accounting for interethnic spillover coefficients. We allow immigrants of other nationalities in the destination country who speak the same language of country $i$, to affect trade between country $n$ and country $i$. In doing so, controlling for the standard ethnic networks' effect, we check whether and to what extent language proximity among immigrants is relevant in overcoming informal trade barriers. The upper part of Table 10 shows that the coefficient of the inter-ethnic spillovers is not significant for import flows regardless of the quality of goods traded, while the same effect turns positive and significant for three of the four quality classes of exports. This is in line with the findings of Bratti et al. (2014). However, as we augment the specification with $S_{i g t}$ and $S_{n g t}$ the inter-ethnic spillover effect turns positive for both imports and exports in all segments with the exception of top-quality products. Perhaps more importantly - as suggested by Bratti et al. (2014) - there is no evidence of an omitted variable bias: the coefficients $\ln \left(m i g_{n i}\right)$ for all quality levels are only marginally affected by the inclusion of the spillover variable and their trend over quality remains unchanged (see Tables 4 and 8).

\section{CONCLUSIONS}

We examine the link between the pro-trade effect of immigrants and product quality. To our knowledge, this topic has not been explored before: existing works mostly focus on the variation of the pro-trade effect of immigrants according to the degree of product heterogeneity. We estimate the effect of ethnic networks in a gravity equation derived from a Ricardian model à la Eaton and Kortum (2002) which predicts international specialisation across varieties based on quality - in line with the findings of Schott (2004) and Fontagné et al. (2008) - conditional on the (reasonable) assumption of an inverse relationship between $\theta_{k}$ and quality. Empirically, we take a similar approach to Gould (1994) and Rauch and Trindade (2002), and at the most detailed classification available, we divide for each HS-6 digit category traded commodities according to the level of quality instead of the degree of product heterogeneity.

We find that the pro-trade elasticity of immigrants exhibit the same trend over quality both for imports and exports. Although the trend of elasticities may arguably be related to the different shares of highly differentiated products across quality classes, we show empirically that the same trend applies to the category of products characterised by the same degree of differentiation according to the Rauch (1999) classification. This suggests that - along with the signals of reference price and whether or not the good is traded on organised exchanges - the quality of traded products is an important determinant of the pro-trade effects of immigrants. Furthermore, regardless of the origins of immigrants, pro-export coefficients are larger in magnitude than those of imports. This gap in favour of exports' elasticities could be

\footnotetext{
${ }^{32}$ Using a large panel of 163 countries, Fontagné et al. (2008) found that the Alchian-Allen effect dominates, that is low-price varieties are slightly more sensitive to transaction costs than high-price ones.
} 
interpreted, other things constant, as an indication of a smaller role of consumer preferences as determinant of the pro-trade effect of immigrants. Our empirical analysis allows for heterogeneity of immigrants, both by country of origin and skill level. As we enlarge the sample by adding immigrants from low and middle-income economies, we find lower pro-trade elasticities (regardless the quality of traded goods). Our results seem to contradict the recent findings of Bratti et al. (2014) and Ehrhart et al. (2014) and also the idea of ethnic networks as a 'substitute' for the weaker institutions of emerging economies (i.e. the fact that trust can substitute for legal enforcement).

In addition, the trend of the pro-trade effect of immigrants over quality varies with the income per capita of their countries of origin. Immigrants from emerging economies exhibit the smallest pro-trade effect on the upper-middle segments, whereas ethnic networks from OECD exert the smallest impact on low-quality products. The same trends over quality are obtained estimating the gravity specification with different sets of fixed effects. We motivate these results by linking the estimates to the North-South specialisation across varieties both in the supply and demand sides. The trend of the pro-import effect of ethnic networks over quality reflects the comparative advantage of their country of origin: immigrants from the South are relatively more effective in facilitating imports from their homelands of mediumlow quality. As for exports, the impact of ethnic networks seems related to the characteristics of demand of their countries of origin: in the OECD sample the largest effect is on the top segments since rich countries spend a larger share of their income on products of higher quality.

Lastly, the pro-trade effect of high-skilled ethnic networks is stronger in each quality segment both for imports and exports. High-skilled immigrants show higher effectiveness in promoting trade with their countries of origin - given their lower liquidity constraints and advantages in human capital. However, the results suggest that the relationship between product quality and pro-trade elasticity of ethnic networks does not depend on the composition of the stock of immigrants by skill level: the trend over quality remains substantially unchanged, meaning that our interpretation related to the link between ethnic networks effect and North-South specialisation across varieties applies also for the high skill.

\section{SUPPORTING INFORMATION}

Additional Supporting Information may be found in the online version of this article:

Appendix S1. Robustness checks.

Appendix S2. Testing the validity of the lagged stocks of immigrants as instruments.

\section{REFERENCES}

Aleksynska, M. and G. Peri (2014), 'Isolating the Network Effect of Immigrants on Trade', The World Economy, 37, 3, 434-35.

Anderson, J. and E. V. Wincoop (2004), 'Trade Costs', Journal of Economic Literature, 42, 3, 691-751.

Bahar, D. (2014), 'Ivreg2hdfe: Stata Module to Estimate an Instrumental Variable Linear Regression Model With two High Dimensional Fixed Effects', Available at http://econpapers.repec.org/software/ bocbocode/s457841.htm (29 July 2014).

Bratti, M., L. D. Benedictis and G. Santoni (2014), 'On the pro-Trade Effects of Immigrants', Review of World Economics (Weltwirtschaftliches Archiv), 150, 3, 557-94. 
Briant, A., P. P. Combes and M. Lafourcade (2014), 'Product Complexity, Quality of Institutions and the pro-Trade Effect of Immigrants', The World Economy, 37, 1, 63-85.

Broda, C. and D. E. Weinstein (2006), 'Globalization and the Gains From Variety', Quarterly Journal of Economics, 121, 2, 541-85.

Brucker, H., S. Capuano and A. Marfouk (2013), 'Education, Gender and International Migration: Insights From a Panel-Dataset 1980-2010', Mimeo (Nuremberg: Institute for Employment Research).

Chen, N. and D. Novy (2011), 'Gravity, Trade Integration, and Heterogeneity Across Industries', Journal of International Economics, 85, 2, 206-21.

Choi, Y., D. Hummels and C. Xiang (2006), 'Explaining Import Variety and Quality: The Role of the Income Distribution', NBER Working Paper 12531 (Boston, MA: NBER).

Combes, P., P. Lafourcade and T. Mayer (2005), 'The Trade-Creating Effects of Business and Social Networks: Evidence From France', Journal of International Economics, 66, 2, 1-29.

Costinot, A., D. Donaldson and I. Komunjer (2012), 'What Goods do Countries Trade? a Quantitative Exploration of Ricardo's Ideas', Review of Economic Studies, 79, 2, 581-608.

Dunlevy, J. (2006), 'The Influence of Corruption and Language on the Protrade Effect of Immigrants: Evidence From the American States', The Review of Economics and Statistics, 88, 1, 182-86.

Dunlevy, J. and W. Hutchinson (1999), 'The Impact of Immigration on American Import Trade in the Late Nineteenth and Twentieth Centuries', Journal of Economic History, 59, 4, 1043-62.

Eaton, J. and S. Kortum (2002), 'Technology, Geography and Trade', Econometrica, 70, 5, 1741-79.

Egger, P., M. V. Ehrlich and D. Nelson (2012), 'Migration and Trade', The World Economy, 35, 2, 21641.

Ehrhart, H., M. L. Goff, E. Rocher and R. J. Singh (2014), 'Does Migration Foster Exports?', World Bank - Policy Research Working Paper 6739 (Washington, DC: World Bank).

Falvey, R. and H. Kierzkowski (1987), 'Product Quality, Intra-industry Trade and (im)Perfect Competition', in H. Kierzkowski (ed.), Protection and Competition in International Trade: Essays in Honor of M. Corden (Oxford: Basil Blackwell), 143-61.

Felbermayr, G. J. and B. Jung (2009), 'The pro-Trade Effect of the Brain Drain: Sorting out Confounding Factors', Economics Letters, 104, 2, 72-5.

Felbermayr, G. J. and F. Toubal (2012), 'Revisiting the Trade-Migration Nexus: Evidence From new OECD Data', World Development, 40, 5, 928-37.

Felbermayr, G., V. Grossmann and W. Kohler (2012), 'Migration, International Trade and Capital Formation: Cause or Effect?', IZA Discussion Paper 6975 (Bonn: IZA).

Fieler, A. C. (2011), 'Nonhomotheticity and Bilateral Trade: Evidence and a Quantitative Explanation', Econometrica, 79, 4, 1069-101.

Flam, H. and E. Helpman (1987), 'Vertical Product Differentiation and North-South Trade', American Economic Review, 77, 5, 810-22.

Fontagné, L., G. Gaulier and S. Zignago (2008), 'Specialization Across Varieties and North-South Competition', Economic Policy, 23, 53, 51-91.

Genc, M., M. Gheasi, P. Nijkamp and J. Poot (2012), 'Migration Impact Assessment. New Horizons in Regional Science', in P. Nijkamp, J. Poot and M. Sahin (eds.), The Impact of Immigration on International Trade: A Meta-Analysis. (Northhampton, MA: Edward Elgar), 301-37.

Giovannetti, G. and M. Lanati (2014), 'The Impact of Product Quality on the Pro-trade Elasticity of Immigrants', Working Paper 11/2014 (Florenze: Disei - Università Degli Studi Di Firenze).

Girma, S. and Z. Yu (2002), 'The Link Between Immigration and Trade: Evidence From the United Kingdom', Review of World Economics (Weltwirtschaftliches Archiv), 138, 1, 115-30.

Gould, D. M. (1994), 'Immigrant Links to the Home Country: Empirical Implications for US Bilateral Trade Flows', The Review of Economics and Statistics, 76, 2, 302-16.

Guimaraes, P. and P. Portugal (2010), 'A Simple Feasible Alternative Procedure to Estimate Models With High-dimensional Fixed Effects', Stata Journal, 10, 4, 628-49.

Hallak, H. C. (2006), 'Product Quality and the Direction of Trade', Journal of International Economics, 68, $1,238-65$.

Head, K. and T. Mayer (2009), 'The Gravity Model in International Trade: Advances and Applications', in S. Bergeijk and P. van Brakman (eds.), Illusory Border Effects: Distance Mismeasurement Inflates Estimates of Home Bias in Trade (Cambridge: Cambridge University Press), 165-92. 
Head, K. and T. Mayer (2014), 'Gravity Equations: Workhorse,Toolkit, and Cookbook', in G. Gopinath, E. Helpman and K. Rogoff (eds.), Handbook of International Economics Vol. 4 (Amsterdam: Elsevier), 131-95.

Head, K. and J. Ries (1998), 'Immigration and Trade Creation: Econometric Evidence From Canada', Canadian Journal of Economics, 31, 1, 47-62.

Herander, M. G. and L. A. Saavedra (2005), 'Exports and the Structure of Immigrant-based Networks: The Role of Geographic Proximity', The Review of Economics and Statistics, 87, 2, 323-35.

Lanati, M. (2014), 'The Trade Migration Link Within a Ricardian Model of Trade', Discussion Paper (Pisa: University of Pisa).

Linder, S. (1961), An Essay on Trade and Transformation (New York: Wiley).

Melitz, M. J. (2000), 'Estimating Firm-level Productivity in Differentiated Product Industries', Working Paper 14404 (Cambridge, MA: Harvard University).

Parsons, R. C. and L. A. Winters (2014), 'International Migration, Trade and Aid A Survey', in R. Lucas (ed.), International Handbook on Migration and Economic Development (Cheltenham: Edward Elgar), 65-112.

Peri, G. and F. Requena-Silvente (2010), 'The Trade Creation Effect of Immigrants: Evidence From the Remarkable Case of Spain', Canadian Journal of Economics, 43, 4, 1433-59.

Rauch, J. E. (1999), 'Networks Versus Markets in International Trade', Journal of International Economics, 48, 1, 7-35.

Rauch, J. E. (2001), 'Business and Social Networks in International Trade', Journal of Economic Literature, 39, 4, 1177-203.

Rauch, J. E. and V. Trindade (2002), 'Ethnic Chinese Networks in International Trade', The Review of Economics and Statistics, 84, 1, 116-30.

Santos Silva, J. and S. Tenreyro (2006), 'The log of Gravity', The Review of Economics and Statistics, 88, 4, 641-58.

Schott, P. (2004), 'Across-Product Versus Within-Product Specialization in International Trade', Quarterly Journal of Economics, 119, 2, 647-78.

Tai, S. (2009), 'Market Structure and the Link Between Migration and Trade', Review of World Economics (Weltwirtschaftliches Archiv), 145, 2, 225-49.

UN (2012), 'Migrants by Origin and Destination: The Role of South-South Migration', Population Facts No. 2012/3 (New York: Department Of Economic and Social Affairs Population Division).

UN (2013), 'The Number of International Migrants Worldwide Reaches 232 Million', Population Facts No. 2013/2 (New York: Department of Economic And Social Affairs Population Division).

UNCTAD (2014), World Investment Report (Geneva: UNCTAD).

UN-OECD (2013), 'World Migration in Figures: A Joint Contribution by un-Desa and the Oecd to the United Nations High-Level Dialogue on Migration and Development', Available at http://www.oecd.org/ els/mig/World-Migration-in-Figures.pdf (accessed 15 August 2016).

Wagner, D., K. Head and J. Ries (2002), 'Immigration and the Trade of Provinces', Scottish Journal of Political Economy, 49, 5, 507-25.

\section{A1 DATA, METHODOLOGIES AND DEFINITIONS}

In this analysis, we use data for the years 1995 and 2000.

\section{Countries}

The whole sample includes 177 countries of origin and 19 OECD destination countries. The destination countries are Australia, Austria, Canada, Chile, Denmark, Finland, France, Germany, Greece, Ireland, the Netherlands, New Zealand, Norway, Portugal, Spain, Sweden, Switzerland and United States. Table A1 lists the 177 countries of origin. In Table A1 countries are divided into two subgroups based on the level of income per capita: OECD (23 
TABLE A1

Countries of Origin

\begin{tabular}{|c|c|c|c|c|c|}
\hline Afghanistan & $\begin{array}{l}\text { Central African } \\
\text { Republic }\end{array}$ & $\begin{array}{l}\text { Gambia, } \\
\text { The }\end{array}$ & Laos & Oman & Sudan \\
\hline Albania & Chad & Georgia & Latvia & Pakistan & Suriname \\
\hline Algeria & Chile $^{\mathrm{a}}$ & Germany $^{\mathrm{a}}$ & Lebanon & Palau & Sweden ${ }^{\mathrm{a}}$ \\
\hline Angola & China & Ghana & Liberia & Panama & Switzerland $^{\mathrm{a}}$ \\
\hline $\begin{array}{l}\text { Antigua and } \\
\text { Barbuda }\end{array}$ & China, Hong Kong SAR & Greece $^{a}$ & Libya & Papua New Guinea & Syria \\
\hline Argentina & China, Macao SAR & Grenada & Lithuania & Paraguay & Tajikistan \\
\hline Armenia & Colombia & Guatemala & Macedonia & Peru & Tanzania \\
\hline Australia $^{a}$ & Comoros & Guinea & Madagascar & Philippines & Thailand \\
\hline Austria $^{a}$ & Congo, Rep. of the & $\begin{array}{l}\text { Guinea- } \\
\text { Bissau }\end{array}$ & Malawi & Poland & Togo \\
\hline Azerbaijan & Costa Rica & Guyana & Malaysia & Portugal $^{\mathrm{a}}$ & Tonga \\
\hline Bahamas, The & Cote d'Ivoire & Haiti & Maldives & Qatar & $\begin{array}{c}\text { Trinidad } \\
\text { Tobago }\end{array}$ \\
\hline Bahrain & Croatia & Honduras & Mali & Russia & Tunisia \\
\hline Bangladesh & Cuba & Hungary & Malta & Rwanda & Turkey \\
\hline Barbados & Cyprus & Iceland $^{\mathrm{a}}$ & $\begin{array}{c}\text { Marshall } \\
\text { Islands }\end{array}$ & $\begin{array}{l}\text { Saint Kitts and } \\
\text { Nevis }\end{array}$ & Turkmenistan \\
\hline Belarus & Czech Republic & India & Mauritania & Saint Lucia & Tuvalu \\
\hline Belgium $^{a}$ & Denmark $^{\mathrm{a}}$ & Indonesia & Mauritius & Saint Vincent & Uganda \\
\hline Belize & Djibouti & Iran & Mexico & Samoa & Ukraine \\
\hline Benin & Dominica & Iraq & Micronesia & San Marino & $\begin{array}{l}\text { United } \\
\text { Kingdom }^{\mathrm{a}}\end{array}$ \\
\hline Bhutan & Dominican Republic & Ireland $^{\mathrm{a}}$ & Moldova & $\begin{array}{l}\text { Sao Tome and } \\
\text { Principe }\end{array}$ & United States ${ }^{\mathrm{a}}$ \\
\hline Bolivia & Ecuador & Israel & Mongolia & Saudi Arabia & Uruguay \\
\hline $\begin{array}{l}\text { Bosnia } \\
\text { Herzegovina }\end{array}$ & Egypt & Italy $^{\mathrm{a}}$ & Morocco & Senegal & Uzbekistan \\
\hline Brazil & El Salvador & Jamaica & Mozambique & Seychelles & Vanuatu \\
\hline Brunei & Equatorial Guinea & Japan $^{\mathrm{a}}$ & Myanmar & Sierra Leone & Venezuela \\
\hline Bulgaria & Eritrea & Jordan & Nepal & Slovakia & Vietnam \\
\hline Burkina Faso & Estonia & Kazakhstan & Netherlands ${ }^{\mathrm{a}}$ & Slovenia & Yemen \\
\hline Burundi & Ethiopia & Kenya & $\begin{array}{l}\text { New } \\
\text { Zealand }^{\mathrm{a}}\end{array}$ & Solomon Islands & Zambia \\
\hline Cambodia & Fiji & Kiribati & Nicaragua & Somalia & Zimbabwe \\
\hline Cameroon & Finland $^{\mathrm{a}}$ & Korea & Niger & South Africa & \\
\hline Canada $^{\mathrm{a}}$ & France $^{\mathrm{a}}$ & Kuwait & Nigeria & Spain & \\
\hline Cape Verde & Gabon & Kyrgyzstan & Norway $^{a}$ & Sri Lanka & \\
\hline
\end{tabular}

Note:

${ }^{\mathrm{a}}$ The 23 countries are the OECD sample whereas the remaining countries are the EME sample.

countries in bold) and EME (154 remaining emerging and developing countries). The OECD sample includes all highly industrialised economies: they all entered OECD prior to 1990 and they were all ranked in the highest quartile of the IMF world's list of GDP per capita. The only exceptions are the inclusion of Chile which entered in 2010 and the exclusion of Turkey. Despite Turkey was part of the OECD prior to 1990, it has not been included in the OECD sample since it belongs to the upper-mid quartile. As a robustness check in the next section, we drop Chile from the group of importers; this exclusion does not affect our main results. We cannot conduct a similar exercise with the inclusion of Turkey among the importers, since the database of Brucker et al. (2013) does not include immigrants resident in Turkey. 


\section{Migration Data}

Migration data are from the recent IAB brain drain dabatase by Brucker et al. (2013). We use the total number of foreign-born individuals aged 25 years and older, resident in one of the 19 OECD destination countries and born in one of the 177 countries of origin. ${ }^{33}$ In our analysis, we divide the total number of bilateral immigrants from the high skilled as in Felbermayr and Toubal (2012). Brucker et al. (2013) label as high skilled those immigrants with tertiary education (higher than high-school leaving certificate or equivalent). Despite the relatively small number of receiving countries, our sample covers an important share of the total migrants population. This is because - according to UN-OECD (2013) - migrants are principally concentrated in a few receiving countries. As reported by UN-OECD (2013), in 2013 half of all international migrants lived in 10 countries: US hosted the largest number (45.8 million), followed by the Russian Federation (11 million); Germany (9.8 million); Saudi Arabia (9.1 million); United Arab Emirates (7.8 million); United Kingdom (7.8 million); France (7.4 million); Canada (7.3 million); Australia (6.5 million); and Spain (6.5 million). Our data set of 19 OECD receiving economies contains seven of these countries. Given the extensive country coverage of Brucker et al. (2013) data set, our sample covers approximately 30 per cent of the world's stock of migrants for the year 2000 and it is representative of some of the main stylised facts that emerge from the latest trends in international migration. These stylised facts are as follows: (i) during the last 20 years the South-North channel has become the main driver of global migration; ${ }^{34}$ (ii) these migrants are predominantly well educated. ${ }^{35}$ As it emerges from Table A2, the predominant share of our sample is South-North migration which accounts for 68.1 per cent of the total stock; in addition, our descriptive statistics in Table 12 obtained as an elaboration of Brucker et al. (2013) database indicates that international migrants who were born in the South and residing in the North increased by 75 per cent between 1995 and 2005, against a rate of 10.2 per cent for North-North migration. Finally, the largest contribution of this rise in South-North migration comes from the high skilled (99.8 per cent).

\section{Geographic Barriers}

Data on weighted distance and all the geographic barriers used in this paper namely common border, common language and the dummy for regional trade agreement (RTA) are from CEPII gravity database. ${ }^{36}$

\footnotetext{
${ }^{33}$ Luxembourg is not included in the list of destination countries given the relatively small size of the country in terms of population and - most importantly - the very limited flows of immigrants and the very large share of zeroes in the bilateral stocks of immigrants.

${ }^{34}$ Since 1990, the migrant stock in the North has increased three times as fast as the migrant stock in the South and in 2010, South-North migrants outnumbered South-South migrants for the first time (see UN 2012).

${ }^{35}$ For virtually all countries of origin, the emigration rate of the highly skilled exceeds the total emigration rate reflecting the selectivity of migration by educational attainment (UN-OECD 2013).

36 Weighted distance calculates the distance between two countries based on bilateral distances between the biggest cities of those two countries: those inter-city distances are weighted by the share of the city in the overall country's population. The CEPII gravity database includes data on distance between $n$ and $i$ based on the following formula from Head and Mayer (2009): dist $_{n i}=\left(\Sigma k \in n\left(\right.\right.$ pop $_{k} /$ pop $\left.\left._{n}\right)\right) \times\left(\Sigma l \in i\left(\right.\right.$ pop $_{l} /$ pop $\left.\left._{i}\right)\right) \times$ dist $_{k l}$, where pop $_{k}$ stands for the population of agglomeration $k$ belonging to country $n$ while pop $_{1}$ is the population of agglomeration $l$ belonging to country $i$.
} 
TABLE A2

Descriptive Statistics - Migrants

\begin{tabular}{lcccc}
\hline Skill level & Total & Low & Medium & High \\
\hline Immigrants divided by countries of origin & & & \\
\hline Origin & & & \\
\hline High Income & $31.9 \%$ & $33.6 \%$ & $34.6 \%$ & $31.3 \%$ \\
Emerging & $68.1 \%$ & $66.4 \%$ & $65.4 \%$ & $68.7 \%$ \\
Growth rates of immigrants by skill level & & & \\
\hline Origin & & & \\
\hline All & & $62.2 \%$ & $49.2 \%$ \\
High Income & $52.0 \%$ & $25.3 \%$ & $18.0 \%$ & $99.8 \%$ \\
Emerging & $10.2 \%$ & $-16.6 \%$ & $87.5 \%$ & \\
\hline
\end{tabular}

Notes:

(i) Upper Part: the first row reports the percentage of immigrants resident in 19 OECD countries and born in highincome countries with respect to the total stock by skill level for the years 1995 and 2000 .

(ii) Data are from Brucker et al. (2013).

(iii) Lower part: the first row reports the growth rate of total immigrants by skill level resident in 19 OECD countries for the period 1990-2005.

(iv) The second and third rows show the correspondent statistics by country of origin.

(v) Data are from Brucker et al. (2013).

\section{Trade Data}

Data on bilateral values and quantities of exports in thousand dollars disaggregated at HS six-digit level are from BACI database (CEPII). Starting from bilateral trade data at the most detailed classification level comparable across countries, we determine the trade unit values for both imports and exports for each six-digit HS category. BACI data set gives information about the value of trade (in thousands of US\$) and the quantity (in tons). We selected the version of BACI with 1992 Harmonised System (HS). EUV is the ratio between the value and the quantity of exports and it stands for our proxy for product quality. Since this strategy makes it impossible to measure the quality level when zero trade flows or zero or no quantities are reported in BACI, those information are dropped.

As robustness check in Table 9, we re-estimate equation (6) using TUV data set developed by CEPII. One of the major issues with BACI dataset is the quality of COMTRADE data on quantity: when value is available missing quantities are estimated using a unique standard unit value defined at the World level which could remove most of the variation in prices across countries. Since BACI is derived from the same data, it shares this limitation. On the contrary, the methodology implemented in TUV relies on the 'tariff lines' information corresponding to the values and quantities of trade declared by individual countries to the UN. These data are processed to provide reliable and comparable unit values across countries at six-digit HS classifications. However, in the Cost of Insurance and Freight (CIF) import unit values in TUV data set rely on importers' declarations and include all trade costs (except tariffs and domestic taxes after the border). The inclusion of these costs in the calculation of unit values can be misleading if we think UV as proxy for quality. On the contrary, in BACI data set CIF costs are estimated and removed from imports values to compute FOB import values. 
Furthermore, the coverage of TUV dataset goes from 2000 until 2013 which makes impossible to exactly replicate the original analysis. In addition, Canada does not appear among the reporters in 2000 and 2001 for both imports and exports, while Norway is not reported in the year 2000. Therefore, the estimates of equation (6) reported in Table 9 are obtained using trade data and unit values for the year $2002(t+2)$.

\section{Differentiated Products}

We estimate the correspondent pro-trade effect of immigrants in each quality class on the percentage of differentiated commodities. For imports, the per cent of differentiated traded products is 50.3, 50.4 and 50.3 per cent for Whole, EME and OECD samples, respectively. As for exports correspondent shares are 52.4, 55.4 and 50.5 per cent, respectively. The differentiated products are defined according to Rauch (1999) classification. In Rauch (1999) homogeneous sectors include goods that are internationally traded in organised exchanges, with a well-defined price. Reference-priced sectors include goods that are not traded in organised exchanges but have reference prices available in specialised publications. Differentiated sectors are those sectors that do not satisfy either of the two previous criteria. In order to obtain the share of differentiated commodities in each class, we proceed as follows: we convert the HS-6 digit classification into five-digit SITC Rev.2 classification using the correspondence table from UN Statistics Division. Then, we assemble goods into four-digit SITC Rev.2 classification in order to be able to merge the database with Rauch (1999) classification. Once the share of differentiated traded products is defined, we proceed as usual by dividing these reduced samples in quartiles and running separate regressions for each quality class.

\section{Inter-ethnic Spillovers}

As in Bratti et al. (2014), we allow for inter-ethnic spillovers, which is to say we allow for immigrants of other nationalities to affect trade between country $i$ and country $n$. With respect to Bratti et al. (2014), we rule out the inter-ethnic proximity based on affinity in trade and we only focus on the definition of proximity based on the common language. To build the spillover variable $\operatorname{spil}_{n i}$ for nationality $i$ in country $n$ we aggregate all immigrants of other nationalities who speak the same language as nationality $i$ and located in the same country. Following the CEPII database, we select the variable comlangethno which for any country pair takes value 1 if a language is spoken by 9 per cent (or more) of the population in both countries and zero otherwise. 